\title{
Xestión e Políticas \\ Culturais nos concellos. \\ Retos ante a COVID-19
}

DOI: 10.17075/xpccrac.2020 
O Consello da Cultura Galega ten entre as súas principais funcións analizar as cuestións relacionadas co patrimonio cultural entendido nun sentido amplo, así como investigar e valorar as necesidades culturais do pobo galego. Dentro destes grandes obxectivos, dende os seus comezos a institución tentou estimular o debate ao redor das diferentes facetas que compoñen a cultura galega. Enténdese que a promoción do intercambio de ideas é enriquecedora e que permite acercar a institución aos axentes culturais e á sociedade en xeral. As cuestións referidas á xestión cultural integran unha desas facetas ás que esta institución tentou achegar contidos e foros para deliberar sobre os principais problemas do goberno da cultura.

Coa declaración do estado de alarma como consecuencia da crise sanitaria que se desenvolve neste momentos, o Consello da Cultura Galega decidiu fornecer de contidos e elementos para a discusión o espazo baleiro que quedaba ao se interromper a cadencia normal de actos culturais, congresos, foros e diversas manifestacións artísticas que deberían estar celebrándose nos últimos meses. Nese marco non só rescatamos gran cantidade de contidos que o Consello da Cultura Galega leva producidos nos últimos 37 anos, senón que tratamos de converter a situación anómala nunha oportunidade para impulsar un debate inmediato e urxente sobre unha etapa incerta cando aínda é dificil imaxinar e avaliar as consecuencias que esta excepcionalidade terá para a cultura. Nas últimas semanas publicamos informes e estatísticas, impulsamos estudos novidosos e aproveitamos a tecnoloxía para tentar manter en marcha día a día, doutro xeito, a actividade do Consello da Cultura Galega. Foi preciso implicar centos de persoas e ducias de institucións e organizacións profesionais: a fortaleza da cultura galega e a calidade humana dos seus axentes mídese tamén na magnífica resposta.

O presente informe é froito dese traballo mancomunado. Non é en si mesmo un pronunciamento institucional do Consello da Cultura Galega. Obedece ao impulso da Comisión técnica de xestión e políticas culturais que foi creada para establecer un marco de referencia dentro do Consello da Cultura Galega onde se puidese debater e estudar unha parte quizais menos vistosa da creación artística e das representacións culturais, pero fundamental para o desenvolvemento cultural do país. Gran parte dos resultados que se recollen neste documento de traballo proveñen dun intenso debate e intercambio de opinións por parte de expertos e expertas de diversos ámbitos, todos cunha grande experiencia e coñecemento especializado, convocados polo Consello da Cultura Galega nun ciclo de tres xornadas centradas na análise dos retos 
afrontados, por mor da COVID-19, na xestión cultural e nas políticas culturais nos concellos. O ciclo en liña Xestión e políticas culturais nos concellos. Retos ante a COVID-19, organizado pola citada Comisión e coordinado por Sergio Lago, pódese seguir a través do web do Consello da Cultura Galega no enderezo https://url2.cl/fCuUk

$\mathrm{O}$ momento en que se produce este documento de traballo e a inmediatez con que se publica implican que seguramente será necesario revisar e actualizar os seus contidos en breve prazo, dada a muda constante que experimenta nestes días o ecosistema cultural galego. En todo caso, publicámolo na confianza de que ofrece un conxunto de datos imprescindible para comprender a complexidade do fenómeno que a crise sanitaria vai supor para a sociedade galega en xeral, e para a cultura en particular. 


\section{Limiar}

Este documento busca sintetizar parte das voces que, durante a vixencia do estado de alarma imposto pola emerxencia sanitaria da COVID-19, reflexionaron arredor dos retos e estratexias de futuro para a xestión e políticas culturais galegas. Centrámonos en achegar unha ollada local, pública e de proximidade.

Partimos das conversas en liña promovidas pola Comisión técnica temporal de xestión e políticas culturais do Consello da Cultura Galega no mes de maio, sumando despois achegas a través de entrevistas e, finalmente, da revisión de publicacións, debates e repositorios de moi diferentes medios e institucións. Todas estas fontes aparecen referenciadas nos distintos apartados se ben, co fin de facilitar a lectura, se optou por unha redacción a xeito de reflexión coral, sumando as ideas que parecían xerar máis consenso.

Dividimos este documento en tres bloques. $\mathrm{O}$ inicial céntrase na grande efervescencia de reflexións durante este momento tan excepcional, en forma de pausa común nas nosas vidas. Quixemos recoller aqueles recursos textuais e audiovisuais máis destacados, como un xeito de intentar preservar unha foto fixa, a cal probablemente mereza a pena revisar xa cunha maior perspectiva.

Os principais retos e posibles estratexias ocupan os bloques seguintes. No segundo, achegámonos a aquelas cuestións que, superado o impacto inicial, se mostraron como as máis urxentes, especialmente no relacionado coa reapertura de espazos e a reactivación de programacións. Recompilamos experiencias, posibles estratexias e ferramentas, así como protocolos de recomendacións hixiénicosanitarias, que axuden a abordar o futuro máis inmediato.

Os debates de fondo, aqueles que probablemente reflicten mellor a fraxilidade do noso ecosistema cultural, quedaron aprazados. A eles adicamos o terceiro e último bloque.

Estes tres meses, entre o 14 de marzo e o 14 de xuño, foron tempos de constante provisionalidade e incertezas. Tamén o serán os que veñan a partir do peche deste documento, coa chegada a Galicia da "nova normalidade". Ata que exista unha vacina ou cura efectiva, a reactivación 
do sector desenvolverase baixo a continua ameaza de novos brotes, peches ou pasos atrás.

Unha crise destas dimensións supón sufrimento, pero tamén oportunidade. O balance final e a capacidade de construír un sector cultural máis resistente para vindeiras crises, que virán, dependerán en gran medida do deseño dunhas mellores políticas culturais. A súa sorte será a nosa sorte.

Sergio Lago | 15 de xuño de 2020 


\section{Unha pausa única}

Os espazos de reflexión sobre a xestión e as políticas culturais en Galicia foron tradicionalmente escasos e cunha participación bastante limitada, polo menos en proporción ás 35.000 persoas $^{1}$ que a cultura emprega en Galicia.

Por esta razón, sen esquecer todas as consecuencias dramáticas dunha pandemia como a da COVID-19, o paro imposto polo estado de alarma en toda a nosa actividade permitiunos observar un número excepcional de encontros sectoriais, debates, informes, artigos e iniciativas institucionais, cunha alta participación de axentes preocupados polo seu futuro.

As urxencias económicas dun sector tan fráxil impuxéronse rapidamente aos debates de fondo pero, aínda así, a segunda quincena de marzo e gran parte do mes de abril de 2020 supuxeron un momento único, no que todos os sectores culturais puideron reflexionar a fondo sobre as súas principais debilidades e fortalezas. Ao final deste primeiro bloque recollemos algúns dos recursos textuais e audiovisuais que consideramos máis destacados para construír unha foto fixa deste momento.

\section{A perspectiva da xestión cultural desde os concellos galegos}

Aínda que o título xa nos dá unhas pistas, neste documento centrarémonos no papel da acción cultural municipal, pública e de proximidade. Esencial tamén para o futuro do sector cultural privado e social, tanto profesional como amador. E o máis importante, a principal administración que debe garantir o dereito de acceso e participación cultural á cidadanía.

Para entender a súa importancia detémonos nalgúns datos. Así, no conxunto do Estado ${ }^{2}$, o gasto liquidado en cultura polas administracións municipais triplica o das comunidades autónomas e supón seis veces máis que

\footnotetext{
${ }^{1}$ Observatorio da Cultura Galega. O emprego cultural en Galicia, 2019 consellodacultura.gal/publicacion.php?id=4348

${ }^{2}$ Ministerio de Cultura y Deporte. Anuario de Estadísticas Culturales 2019 culturaydeporte.gob.es/servicios-alciudadano/estadisticas/cultura/mc/naec/2019.html
} 
DOCUMENTOS DE TRABALLO

o estatal. En Galicia ${ }^{3}$, no ano 2017 o gasto liquidado en cultura por parte das administracións dos 313 concellos galegos ascendeu a 138,1 millóns de euros, cando no mesmo período a Xunta de Galicia gastaba 75,2 millóns e as deputacións 35,4 millóns. Ademais, unha parte importante dese gasto autonómico e provincial distribúese para financiar as programacións, persoal e iniciativas culturais municipais. Vemos polo tanto que, en último termo, son os pequenos equipos das entidades locais, e mesmo os profesionais en solitario, os que deseñan e executan as principais liñas de traballo cultural no país.

A principal entidade vertebradora da profesión é a Asociación Galega de Profesionais da Xestión Cultural (AGPXC) ${ }^{4}$, unha das máis activas durante a pandemia e que nos primeiros momentos liderou unha iniciativa de unión intersectorial inédita en Galicia. A través dun grupo de traballo conformado por 17 asociacións profesionais redactouse unha "Proposta conxunta de medidas específicas dirixidas ao sector cultural galego polas consecuencias da Covid19" 5 . Este documento dirixiuse o 20 de marzo á Consellería de Cultura e Turismo da Xunta de Galicia e participaron na súa elaboración: Academia Galega de Teatro (AGT), Asociación de Escritoras/es en Lingua Galega (AELG), Asociación Empresarial Festivais de Galicia, Asociación Galega de Empresas Musicais (AGEM), Asociación Galega de Profesionais da Ilustración (AGPI), Asociación Galega de Profesionais da Xestión Cultural (AGPXC), Asociación Galega de Salas de Música ao Vivo (Clubtura), Asociación Galega de Videoxogos e Contidos Interactivos, Asociación de Produtores Técnicos de Espectáculos de Galicia (APTEGA), Asociación Profesional de Artistas de Galicia (A Colectiva), Culturgal Feira Industrias Culturais, Coordinadora Galega de Festivais de Cinema - Proxecta, EGANET, Escena Galega, Músicas Ao Vivo, Plataforma Afectadas polo Centro Coreográfico Galego (PACCG) e a Unión de Cooperativas Galegas (Espazo Coop).

A finais de abril, xa sendo 20 as entidades asinantes, volveuse facer público un novo comunicado ${ }^{6}$ denunciando a falta de resposta e de medidas específicas de apoio. Pero poucos días despois o Goberno galego presentou o "Plan de reactivación dos sectores cultural e turístico fronte aos efectos derivados da COVID-19"7. Aínda que o plan non responde ás expectativas de

\footnotetext{
${ }^{3}$ Observatorio da Cultura Galega. observatorio.consellodacultura.gal

${ }^{4}$ xestoresculturais.gal | 13-03-20 O sector cultural reacciona ante o impacto económico do parón de actividade culturagalega.gal/noticia.php?id=30863 | 23-03-20 Proposta de medidas específicas para o sector cultural i.gal/agxc-covid23-03-20

${ }^{5}$ xestoresculturais.gal/agpxc/documentos/ | xestoresculturais.gal/wpcontent/uploads/2020/04/Documento-unificado.pdf | culturagalega.gal/noticia.php?id=30949

${ }^{6}$ praza.gal/cultura/o-sector-cultural-galego-denuncia-que-a-xunta-segue-sencomprometer-medidas-de-apoio-ante-a-crise-do-coronavirus

${ }^{7}$ ficheiros-web.xunta.gal/cultura/publicacions/plan-reactivacion-cultural-turistica.pdf
} 
gran parte do sector, esta fronte conxunta foi disipándose tendo en conta as particularidades de cada disciplina.

En calquera caso, tanto esta experiencia vertebradora como as canles abertas deixan a esperanza de poder abordar retos comúns á cultura galega de xeito conxunto no futuro. 


\section{Unha pausa única | recursos para ampliar}

Previamente á elaboración deste informe, durante maio e os primeiros días de xuño, desde o Consello da Cultura Galega promoveuse un ciclo políticas culturais nos concellos | Retos ante a COVID-19”. de conversas en liña arredor da "Xestión e

$\mathcal{O}$ detalle do ciclo

\section{Xoves 14 de maio de 2020 | Onde estamos? Cara a onde camiñar?}

Unha diagnose inicial e primeira aproximación aos retos e inquedanzas na xestión cultural municipal. Participaron catro profesionais galegos que traballan en contextos territoriais diferentes, como mostra representativa das diversas realidades e enfoques de traballo que existen no noso territorio.

- Presentación institucional: Rosario Álvarez Blanco, presidenta do Consello da Cultura Galega.

- Marcos Lorenzo (membro da Sección de

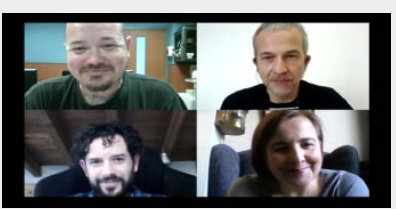
Lingua, Literatura e Comunicación do CCG| Técnico de Cultura en Ferrol)

- Pilar Portela (Presidenta Asociación Galega de Profesionais da Xestión Cultural AGPXC| Directora-Xerente do Pazo da Cultura de Pontevedra)

- Alberto García (membro da Comisión técnica temporal de xestión e políticas culturais do Consello da Cultura Galega do CCG | Técnico de Cultura en Boiro)

- Juan Antonio Seara (Técnico de Cultura en Allariz) 
Xoves 28 de maio de 2020 | Reflexións inspiradoras

Un achegamento a experiencias e liñas de traballo en cultura que se desenvolven noutros territorios, sempre dende perspectivas próximas e trasladables á realidade galega. Permite descubrir visións afastadas das lóxicas dos grandes núcleos culturais, habituais dominadoras do relato nos medios e espazos de debate sobre o sector cultural.

- Marián Fernández, (membro da Comisión técnica temporal de xestión e políticas culturais do Consello da Cultura Galega | Socia en O Cable Inglés)

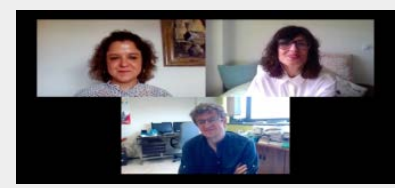

- Pau Rausell (Director da Área de Investigación en Economía da Cultura e Turismo - Econcult. Universidade de València)

- Ma Camino Barcenilla Tirapu (Xefa da Sección de Recursos e Desenvolvemento Estratéxico da Dirección Xeral de Cultura-Institución Príncipe de Viana do Goberno de Navarra)

\section{OUTROS RECURSOS}

\section{RECURSOS AUDIOVISUAIS}

- Diálogos Confinados. Unha iniciativa do Consello da Cultura Galega en forma de pílulas audiovisuais, co obxectivo de tomarlle o pulso á cultura galega nesta situación de parálise provocada pola COVID-19.

- Arqueoloxía de xestión: consellodacultura.gal/evento.php?id $=201000$

- Ilustración: consellodacultura.gal/evento.php?id=201002

- Fundacións: consellodacultura.gal/evento.php?id=201006

- Galerismo e mercado da arte: consellodacultura.gal/evento.php?id=201008

- Creación e xestión cultural nas letras: consellodacultura.gal/evento.php?id=201011

- Videoxogos: consellodacultura.gal/evento.php?id=201033

- Audiovisual: consellodacultura.gal/evento.php?id=201037

- Deseño: consellodacultura.gal/evento.php?id=201039 
- Foros \#Aculturasegue. Reflexións sobre a cultura na era post-COVID-19 Unha iniciativa da Consellería de Cultura e Turismo, a través da Fundación Cidade da Cultura de Galicia, e coa colaboración do Xacobeo 2021. cidadedacultura.gal/gl/evento/foros-aculturasegue-reflexions-sobrecultura-na-era-post-covid19

o Retos nos contidos dixitais da cultura, con Manuel Gago e Olga Sevillano Pintado: cidadedacultura.gal/gl/evento/forosaculturasegue-i-retos-nos-contidos-dixitais-da-cultura

o Retos do sector das artes escénicas na era post COVID-19, con Marta Pazos e Carlus Padrissa: cidadedacultura.gal/gl/node/7803

o Retos do sector da música na era post COVID-19, con Sabela García Fonte e Juan Ángel Vela del Campo: cidadedacultura.gal/gl/evento/foros-aculturasegue-iii-retos-dosector-da-musica-na-era-post-covid-19

o Retos do sector do libro na era post COVID-19, con Anxa Correa e Santiago Fernández de Caleya: cidadedacultura.gal/gl/evento/forosaculturasegue-iv-retos-do-sector-do-libro-na-era-post-covid-19

o Retos do sector do audiovisual na era poscovid-19, con Carla Simón e Alfonso Blanco: cidadedacultura.gal/gl/evento/foros-aculturaseguev-retos-do-sector-audiovisual-na-era-poscovid-19

- A confianza dos consumidores cara á participación en eventos culturais e o perfil do consumidor na era poscovid (pendente de realización ao peche deste documento)

o Novos formatos e mercados (pendente de realización ao peche deste documento)

o Novas fórmulas de xestión de dispositivos culturais (pendente de realización ao peche deste documento)

- A cultura poscovid-19 en Galiza. Mesa redonda organizada por Varanda Viva, na que participaron Alberto García, Encarna Lago, Julio Gómez, Fran Quiroga e Carmen Fouces (05 de maio): facebook.com/106855474325041/videos/232433028178603/ | crónica de Xermán Hermida en culturagalega.gal/noticia.php?id=31096

- A resposta da cultura galega ao plan de reactivación da Xunta. Mesa redonda organizada por Varanda Viva, coa participación de Alberto García, Pela del Álamo, Tomi Legido e Mercedes Queixas (20 de maio): facebook.com/106855474325041/videos/1218112508524332/

\section{DOCUMENTOS DE TRABALLO DO OBSERVATORIO DA CULTURA GALEGA}

- Conxuntura laboral do mes de marzo de 2020 nas principais ramas de actividade cultural: consellodacultura.gal/publicacion.php?id=4361

- O sector da música popular en Galicia perante a crise da COVID-19 consellodacultura.gal/publicacion.php?id=4369

- O sector do libro galego perante a crise da COVID-19 consellodacultura.gal/publicacion.php?id=4360

- Conxuntura estatística do ámbito cultural 
ARTIGOS (membros da Comisión técnica temporal de xestión e políticas culturais do Consello da Cultura Galega)

- Precisamos da cultura. Xavier Campos (29 de marzo): nosdiario.gal/opinion/xavier-campos/precisamos-dacultura/20200329124031094147.html

- O coronavirus e a cultura. Marcos Lorenzo (10 de abril): lavozdegalicia.es/noticia/opinion/2020/04/10/coronaviruscultura/0003_202004G10P28992.htm

- Cultura sostible. Alberto García (19 de abril): nosdiario.gal/opinion/albertogarcia/cultura-sostible/20200417130455095458.html

- O Coronavirus e a Cultura. Xavier Campos (Tempos Novos, 276, maio)

OUTROS RECURSOS AUdIOVISUAIS, ARTIGOS e PUBLICACIÓNS (ámbito galego, estatal e internacional, de interese para o contexto galego)

- The Compendium of Cultural Policies \& Trends in times of Covid-19. The Boekman Foundation: culturalpolicies.net/covid-19 | culturalpolicies.net/covid-19/country-reports/sp/

- A collaborative map to track the coronavirus policy measures. KEA: keanet.eu/collaborative-map-covid-19-policy-measures/

- Coronavirus: Resources: Arts, Culture and Cultural Mobility. On the Move - CircoStrada: http://on-the-move.org/news/article/20675/corona-virusresources-arts-culture-and-cultural/

- Iniciativas culturales destacadas impulsadas en los países con motivo de la pandemia y la cuarentena. Organización de Estados Iberoamericanos (OEI) (Actualizado o 29 de maio): oei.es/cultura-covid-19/iniciativas

- Recursos para unha aproximación a Portugal: culturacovid19.gov.pt/I nos.uminho.pt/Article.aspx?id=3503 POLOBs - CECs - Manuel Gama (coord.)

- Perspectivas de futuro para artistas y profesionales de la cultura. Observatorio Vasco de la Cultura: kultura.ejgv.euskadi.eus/r4619803/es/contenidos/informacion/keb_artista_etorkizuneko_2020/es_def/i ndex.shtml

- Repositorio de documentación xurdida durante a crise da Covid-19. Interacció - CERC - Diputació Barcelona: cercles.diba.cat/cgi-bin/koha/opacshelves.pl?op=view\&shelfnumber $=49$

- Cultura en 300 paraules. Iniciativa do Consell Nacional de la Cultura i de les Arts de Catalunya, que recolle breves reflexións de 150 axentes culturais durante a crise: conca.gencat.cat/ca/cultura-en-300-paraules/

- La magnitud de la tragedia. No blog da empresa Teknecultura, expertos en xestión de datos de audiencias publicaron varios artigos valorando a situación en termos de previsións de impacto no sector cultural (marzo a 
maio): https://teknecultura.com/bloc/la-magnitud-de-la-tragedia-2

- Reflexiones sobre el impacto del Covid-19 en la cultura. Lluís Bonet $\mathrm{i}$ Agustí (12 a 29 de abril):

0 lluisbonet.blogspot.com/2020/04/reflexiones-sobre-el-impacto-del-covid.html

O lluisbonet.blogspot.com/2020/04/reflexiones-sobre-el-impacto-del-covid_13.html

O lluisbonet.blogspot.com/2020/04/reflexiones-sobre-el-impacto-del-covid_16.html

O lluisbonet.blogspot.com/2020/04/reflexiones-sobre-el-impacto-del-covid_23.html

0 lluisbonet.blogspot.com/2020/04/reflexiones-sobre-el-impacto-del-covid 29.html

- Es ahora o nunca. Gemma Carbó, presidenta Patronato Fundación Interarts (23 de marzo): interarts.net/noticias/es-ahora-o-nunca/?lang=es

- En tiempos de crisis, las personas necesitan la cultura. Ernesto Ottone R., subdirector xeral de Cultura da UNESCO (29 de marzo): https://es.unesco.org/news/tiempos-crisis-personas-necesitan-cultura

- 52 medidas extraordinarias para afrontar las consecuencias de la crisis provocada por el COVID-19. Documento conxunto das 33 principais entidades estatais do sector das Artes Escénicas e da Música (10 de abril): redescena.net/redaccion/2020/04/52MedidasCovidArtesEscenicasMus ica.pdf

- El museo del futuro se despide de las exposiciones de masas. Peio $\mathrm{H}$. Riaño (13 de abril): elpais.com/cultura/2020-04-13/el-museo-del-futuro-sedespide-de-las-exposiciones-de-masas.html

- Un futur en suspensió. Recompilación de artigos sobre posibles futuros escenarios para a cultura. Interacció - CERC - Diputació Barcelona (17 de abril): interaccio.diba.cat/CIDOC/blogs/2020/futur-suspensio

- No tengas miedo: cultura local en el cercano día después. Oriol Martí Sambola e Àngel Mestres (21 de abril): blog.transit.es/no-tengas-miedocultura-local-en-el-cercano-dia-despues/ (No blog da empresa Trànsit Projectes acolleron unha serie de reflexións colectivas, das que esta é tan só un exemplo)

- Music Fest Meeting. Encontro do sector musical, con importante presenza galega, que inclúe dez mesas temáticas onde se abordan claves de presente e futuro (20-24 de abril): musicfestmeeting.com

- Cultura de puertas cerradas. Reportaxe de Informe Semanal (TVE), que recolle unha visión bastante plural sobre o impacto da pandemia nos diferentes sectores e perfís profesionais da cultura ( 25 de abril): rtve.es/alacarta/videos/informe-semanal/informe-semanal-culturapuertas-cerradas/5564583/

- Xente que traballa na cultura, por unha renda básica universal e incondicional. Indigestió (30 de abril): nativa.cat/2020/04/gent-quetreballa-en-cultura-per-una-renda-basica-universal-i-incondicional/\#galego

- La cultura por hacer y la cultura por venir. Festival Frena la Curva. Con Benito Burgos (Ministerio de Cultura), José Luis de Vicente, María Montesino de la Iglesia e Susana Moliner (Grigri Projects) (02 de maio): youtube.com $/$ watch?v=uzHAZIB_0bk\&feature $=$ youtu.be\&t $=6836$

- Reinventar a cultura. Manuel Gago (02 de maio). 
- Tenemos que centrar muy bien el tiro sobre cuál es el rol que queremos que la cultura juegue en el futuro de la sociedad. Entrevista con Roberto Gómez de la Iglesia (03 de maio): noticiasdealava.eus/cultura/2020/05/03/centrar-tiro-rol-queremoscultura/1025248.html

- Plans de xoc per a la cultura - Ciutats i Covid-19. Interacció - CERC Diputació Barcelona (05 de maio): interaccio.diba.cat/blogs/2020/05/07/plans-de-xoc-per-cultura-ciutatscovid-19

- Los modos de la multitud (I). Las Prácticas Banales: comportamientos que afectan al contexto socio-cultural. Javier Martín (05 de maio): teatron.com/javiermartin/blog/2020/05/05/los-modos-de-la-multitud-i-laspracticas-banales-comportamientos-que-afectan-al-contexto-socio-cultural/

- Cuando el conflicto nos elige. Marta Domènech i Rubén Martínez (06 de maio): https://nativa.cat/2020/05/cuando-el-conflicto-nos-elige/

- Por qué están ganando las tecnológicas: Netflix y el 'lumpenartista'. Esteban Hernández (09 de maio): blogs.elconfidencial.com/espana/postpolitica/2020-05-09/culturapandemia-tecnologicas-concentracion-netflix_2587075/

- Faladoiro pola igualdade. Rede Museística Provincial de Lugo (12 de maio): facebook.com/redemuseisticaprovincial/videos/234280517669876/

- Por qué Errata naturae no publicará ningún libro en los próximos meses (14 de maio): erratanaturae.com/hades/wp-content/uploads/Jinetes-en-latormenta.pdf

- Tras la pandemia: ¿museos más justos, sostenibles y sociales? Santos M. Mateos (17 de maio): theconversation.com/tras-la-pandemia-museos-masjustos-sostenibles-y-sociales-137123

- Informe sobre la Situación Laboral de las Educadoras y Mediadoras Culturales en el marco del COVID-19. AMECUM, Asociación de Mediadoras Culturales de Madrid (18 de maio): amecum.es/portfolio/situacion-laboral$\underline{\text { covid-19 }}$

- Análise e valoración do Plan de Reactivación do Sector Cultural. Belén Bermejo (26 de maio): facebook.com/photo.php?fbid=2413646728738768\&set $=$ a. $202757973160999 \&$ type $=3 \&$ theater

- Cultural Policy Designers Network. Interview with Cristina Farinha (Portugal) (28 de maio): youtu.be/flgyRbR85M4

- Notas para un museo por venir. Pablo Martínez (28 de maio): ctxt.es/es/20200501/Culturas/32354/Pablo-Martinez-arte-ministeriopandemia-covid-19-centros-de-arte-ecologismo-queer.htm 
- Cultura para un nuevo modelo de desarrollo. Truncar la pirámide de Maslow y ver la cultura como eje de vida. Roberto Gómez de la Iglesia (31 de maio): t.co/PO7UbGh5Lm?amp=1

- La cultura como herramienta imprescindible hacia una sociedad más crítica y cohesionada. Debate con Edurne Ormazabal, Santi Eraso, Claude Bussac e Asier Mendizabal (03 de xuño): youtube.com/watch?v=y43JmW0wiQ | Eta orain, zer (y ahora qué). Notas arredor deste debate no blog de Santi Eraso: santieraso.wordpress.com/2020/06/04/eta-orain-zer-y-ahora-quenotas-para-un-debate/

- Pílulas críticas arredor da COVID-19. Un proxecto de Axóuxere Editora, con Ania González (08 de xuño): https://youtu.be/RWzTlO5-NTo

- Catalizadoras de Conexións. Como tecer alianzas asociación / escola / museo. Antes, agora e despois... as persoas no centro. Debate con Encarna Lago, Cristina Alonso, Ana Pérez; Vanesa (11 de xuño): facebook.com/watch/live/?v=721128588429406

\section{OUTRAS FONTES CONSULTADAS}

- O portal da cultura en Galicia | Consello da Cultura Galega: culturagalega.gal

- Erregueté| Revista Galega de Teatro: erreguete.gal 


\section{O camiño cara á nova normalidade}

O sector cultural foi un dos primeiros en paralizar a súa actividade e xa desde os primeiros momentos se intuía que sería dos últimos en retomala, polo menos de forma similar a como se viña desenvolvendo ata o momento. O tempo que isto levase tamén era unha grande incógnita, así como os pasos graduais que se deberían transitar neste camiño.

Para os efectos de contextualizar lecturas futuras deste documento, detallamos a evolución cronolóxica e as principais limitacións da actividade cultural entre marzo e xuño de 2020:

- A posibilidade de que a aparición dun novo virus en China podería chegar a ter un impacto real na nosa actividade comezou a resoar e culminou co anuncio oficial, o 12 de febreiro, da cancelación do evento Mobile World Congress, a gran feira tecnolóxica prevista en Barcelona entre o 24 e o 27 dese mesmo mes. Pero non é ata a semana do 9 de marzo, na que se constata que existe xa transmisión comunitaria en diferentes puntos da Península, cando comezan a precipitarse cancelacións preventivas de actividades, o posterior peche de espazos públicos e, finalmente, o sábado 14 de marzo, o Real decreto ${ }^{8}$ que declara o estado de alarma en todo o Estado.

- Desde esa data prodúcese o "confinamento" da poboación nos seus fogares, agás para desenvolver traballos en sectores esenciais, entre os que non se atopaba o cultural.

- A chamada "desescalada", que permitiu alixeirar as restricións para toda a cidadanía e a reactivación gradual de actividades económicas, dividiuse en sucesivas fases ${ }^{9}$, do 04 de maio ao 14 de xuño no caso galego. Non foi homoxénea en todo o ámbito estatal, pero no noso territorio a evolución si foi compartida por igual en todas as provincias.

- A “nova normalidade”, que Galicia estreou o luns 15 de xuño, regulouse a través dun Real decreto-lei ${ }^{10}$ que permite xa a mobilidade entre

\footnotetext{
${ }^{8}$ Real Decreto 463/2020, de 14 de marzo, por el que se declara el estado de alarma para la gestión de la situación de crisis sanitaria ocasionada por el COVID-19 boe.es/eli/es/rd/2020/03/14/463/con

${ }^{9}$ A previsión da desescalada cultural. Un artigo de culturagalega.gal que repasa o tema e que inclúe a recompilación doutros artigos en medios de comunicación galegos culturagalega.gal/noticia.php?id=31044

${ }^{10}$ Real Decreto-ley 21/2020, de 9 de junio, de medidas urgentes de prevención, contención y coordinación para hacer frente a la crisis sanitaria ocasionada por el COVID-19 boe.es/diario boe/txt.php?id=BOE-A-2020-5895
} 
territorios que estean na mesma fase. Contempla a súa vixencia ata que exista unha vacina ou cura efectiva ante a COVID-19. No ámbito da cultura e dos espectáculos públicos deixa nas mans das comunidades autónomas a fixación de capacidades e outras cuestións específicas. Marca, iso si, tres premisas obrigatorias: o uso de máscara, manter una distancia de 1,5 metros entre persoas e evitar as aglomeracións. O 13 de xuño a Consellería de Sanidade publica no Diario Oficial de Galicia $(\mathrm{DOG})^{11}$ medidas de prevención complementarias, que detallaremos en seguintes apartados.

A continuación analizamos algunhas experiencias moi ligadas ao contexto destas semanas de confinamento e desescalada. Pero sobre todo centrámonos nas liñas de acción que se identificaron como prioritarias para o futuro inmediato da xestión e políticas culturais en Galicia: protocolos para reactivar liñas de traballo, medidas para coidar o ecosistema cultural do territorio, a exploración de novos formatos e a necesidade de abordar a transformación dixital.

\section{A reactivación de programacións e espazos culturais}

Aínda que se debateu sobre modelos de políticas culturais alternativas e algúns concellos experimentaron con formatos e experiencias dixitais, xa durante o "confinamento" e a "desescalada" se fixo evidente que gran parte do sector cultural galego, público e privado, non tiña plan alternativo se non se retomaba a actividade presencial o antes posible.

Así, no mes de maio, unha vez que se foi aclarando o escenario e as pautas que marcarían os meses de verán, a maioría de profesionais centráronse nos aspectos máis prácticos neste sentido. Nun primeiro momento para adaptarse ás medidas que ían xurdindo nas fases de "desescalada", sobre todo no referente a espazos que puideron ir abrindo gradualmente, como as bibliotecas e museos. Pero tamén aos preparativos para re-programar a súa actividade, sempre baixo as dúas premisas que marcan esta nova etapa: garantir a seguridade e xerar confianza no público.

Será esencial a prudencia e o compromiso conxunto de todos os axentes culturais para cumprir as medidas sanitarias, xa que calquera paso atrás pode resultar traumático. Posibles contaxios que, ademais de pór en risco a saúde das persoas, provoquen peches por corentena dos espazos ou empresas afectadas. E tamén por casos de mala praxe que rompan este proceso de xeración de

\footnotetext{
${ }^{11}$ Acordo do Consello da Xunta de Galicia, do 12 de xuño de 2020, sobre medidas de prevención necesarias para facer fronte á crise sanitaria ocasionada pola COVID-19, unha vez superada a fase III do Plan para a transición cara a unha nova normalidade xunta.gal/dog/Publicados/2020/20200613/AnuncioC3K1-120620-1_gl.html
} 
confianza nos eventos e espazos de programación cultural, que lembremos que será longo, ata que exista unha cura efectiva ou vacina contra a COVID-19.

Neste sentido, entre profesionais da produción técnica e da prevención de riscos, unha vez coñecidos os primeiros protocolos, considérase que dende o punto de vista loxístico as medidas que implementar resultan razoables para quen xa traballase con rigor dentro da normativa preexistente. Tamén, que esta crise pode supoñer un certo impulso para a concienciación sobre a importancia de incorporar asistencias técnicas profesionais e formarse nas normativas de seguridade e prevención de riscos esenciais para operar no sector cultural.

Debullamos a continuación as principais guías e protocolos publicados ata o 15 de xuño. Trátase en todos os casos de recomendacións e polo tanto de puntos de partida, pero cada espazo debe aplicar a súa propia folla de ruta para implementalas. Por achegarnos a algunha das recomendacións principais, parten de garantir a distancia de seguridade e a hixiene, especialmente de mans. Tamén vemos que deben preverse cuestións ligadas ao control de accesos do público, á protección das persoas traballadoras, á existencia de recursos hixiénicos segundo a arquitectura de cada recinto e, na medida do posible, a controlar o cumprimento das medidas xerais que debe obedecer toda a cidadanía entre o público asistente.

DOCUMENTOS DE TRABALLO

\section{Os espazos de programación cultural}

Dende o punto de vista técnico e preventivo, o Instituto de Seguridade e Saúde Laboral de Galicia (ISSGA) en colaboración coa Asociación Galega de Empresas Musicais (AGEM) e a Asociación de Empresas Tecnolóxicas e Servizos Audiovisuais de Galicia (AGATEC) manteñen en continua actualización un documento ${ }^{12}$ de referencia no que se recollen as recomendacións preventivas básicas para montaxes audiovisuais de eventos en recintos estables ou temporais. De igual xeito, en colaboración co Clúster Audiovisual Galego, tamén ofrecen a mesma información para gravacións de contidos audiovisuais.

Pola súa parte, a Rede Española de Teatros, Auditorios, Festivais e Circuítos de titularidade pública (RedEscena), da que forman parte trece espazos galegos, o FIOT Carballo e a propia Rede Galega de Teatros e Auditorios (RGTA) da Axencia Galega das Industrias Culturais (AGADIC), deseñou co apoio do Instituto Nacional de las Artes Escénicas y de la Música (INAEM) un protocolo ${ }^{13}$ de medidas sanitarias cara á súa reactivación. Aínda que sen rango legal, nel atópanse recomendacións e ferramentas prácticas para a reapertura dos espazos escénicos, a realización de festivais e a reactivación da exhibición de artes escénicas en xeral. O propio INAEM publicou posteriormente unha

${ }_{13} \frac{\text { issga.xunta.gal/portal/contido/actualidade/novas/nova_1279.html }}{\text { redescena.net/redaccion/2020/05/LARED COVID.pdf }}$ 
"Guía de Boas Prácticas para o reinicio da actividade escénica”", creada a partir das achegas de distintas asociacións estatais do sector, que inclúe medidas e recomendacións para retomar a realización de espectáculos.

A Xunta de Galicia, no DOG do 13 de xuño, establece que na "nova normalidade" a ocupación en todos os recintos pechados non debería superar o $75 \%$ da súa capacidade. Tamén achega algunhas medidas de hixiene e prevención comúns aos colectivos artísticos e, xa de xeito máis detallado, para a entrada, saída e circulación de público espectador en cines, teatros, auditorios, circos de toldo e espazos similares, así como en recintos ao aire libre e noutros locais e establecementos destinados a espectáculos públicos e actividades recreativas.

Con estes documentos xa resulta posible planificar a volta á actividade escénica. En calquera caso, aínda que algúns teatros e auditorios municipais como o Centro Cultural e Xuvenil de Muros ou o Teatro Rosalía de Castro da Coruña comezan a programar datas xa en xuño, a maioría parece que aprazará ata o outono a súa reapertura. É o caso tamén de salas independentes, como as pertencentes á estatal Red de Teatros Alternativos -entre os que se atopan o Teatro Ensalle e a sala Ártika de Vigo-, que centrarán os seus esforzos até setembro no apoio aos procesos de creación e na adaptación dos espazos ás novas condicións de exhibición.

\section{Museos, patrimonio, bibliotecas e outros espazos de xestión municipal}

Á falta do desenvolvemento de posibles guías específicas por parte das autoridades culturais e turísticas galegas, a Xunta de Galicia, no DOG do 13 de xuño, establece unha ocupación máxima do $75 \%$ en espazos culturais, turísticos e de ocio. Tamén recomenda este $75 \%$ de ocupación en eventos que impliquen concorrencia de varias persoas nun mesmo espazo, tales como actividades educativas, conferencias, talleres, concertos e, en xeral, programas públicos. Seguindo coas recomendacións para actividades en recintos pechados, noutros apartados sinálase un máximo de 25 persoas, incluídos facilitadores, monitores ou guías.

Congresos, reunións e conferencias poden realizarse ao $75 \%$ da capacidade pero, xa en cifras concretas, ata 300 persoas sentadas en espazos pechados e mil se é ao aire libre. Tamén se detallan recomendacións para centros de interpretación e visitantes, aulas da natureza, casetas e puntos de información, actividades de tempo libre dirixidas á poboación infantil e xuvenil, centros recreativos turísticos, zoolóxicos e acuarios.

Finalmente, recomendan promover actividades que eviten a proximidade fisica entre os participantes, primar as actividades de realización

\footnotetext{
${ }^{14}$ culturaydeporte.gob.es/cultura/artesescenicas/contenedora-noticiasprensa/a2020/junio/guia-buenas-praticas-covid.html
} 
autónoma e reforzar o deseño de recursos educativos, científicos e divulgativos de carácter dixital que permitan a función como institucións educativas e transmisoras de coñecemento por medios alternativos aos presenciais. $\mathrm{Na}$ medida do posible, o uso dos elementos expostos deseñados para un uso táctil por parte do visitante estará inhabilitado e, así mesmo, estableceranse percorridos obrigatorios para separar circulacións ou organizaranse horarios de visitas para evitar aglomeracións e interferencias entre grupos.

Xa de xeito máis específico para museos e sitios patrimoniais, o Consello Internacional de Monumentos e Sitios (ICOMOS), unha organización internacional non gobernamental asociada coa UNESCO, recompila na súa web $^{15}$ as principais informacións, recomendacións e experiencias para responsables de museos, centros de interpretación e de patrimonio cultural fronte á crise da COVID-19. Outro recurso importante parte da Secretaría de Estado de Turismo, que, a través do Instituto para la Calidad Turística Española (ICTE), publica un documento ${ }^{16}$ tamén para este eido.

As bibliotecas, pola súa parte, teñen na web $^{17}$ da Federación Internacional de Asociacións de Bibliotecarios e Bibliotecas (IFLA) o principal organismo internacional neste eido, un repositorio actualizado de recursos.

DOCUMENTOS DE TRABALLO CCG

\section{Os eventos ao aire libre}

Con respecto ás actividades ao aire libre, a indicación xeral do Decreto-lei da "nova normalidade" de "evitar aglomeracións", entendidas como unha agrupación de persoas onde non é posible manter distancia de seguridade nin a trazabilidade de posibles contaxios, facía pouco probable que as entidades locais puidesen autorizar e aínda menos promover eventos onde isto resulte inevitable, como por exemplo as festas populares tal como as entendemos.

Así, se ben o verán permite desenvolver actuacións ao aire libre con maiores marxes de capacidade, os protocolos de hixiene e seguridade deberían ser moi similares aos de eventos promovidos en recintos pechados, polo tanto deberían realizarse en espazos preferentemente delimitados. Isto supón un reto loxístico que leva a que xurdan propostas para intentar salvar eventos masivos. Poñemos de exemplo o "Sistema Marko"18, que intenta promover a dirección de Montgorock Xàbia Festival. A dubidosa viabilidade e aplicación desta proposta, ou doutras similares, na realidade da maioría de concellos galegos mostraba a dificultade de atopar alternativas para este verán que non pasasen polos pequenos formatos.

15 icomos.es/covid-19/

16 femp.femp.es/files/566-2740-archivo/Museos-y-sitios-patrimoniales-COVID.pdf

17 ifla.org/ES/node/92983

18 abc.es/cultura/abci-seran-festivales-musica-coronavirus-202005051412_video.html 
Pola contra, a Xunta de Galicia, no DOG do 13 de xuño, anuncia que "poderá permitir" o restablecemento, a partir do 1 de xullo, de festas, verbenas e outros eventos populares, así como as atraccións de feiras. Sinala, iso si, que "sempre que a evolución da situación epidemiolóxica así o aconselle" e "nas condicións que previamente a Administración autonómica así o estableza”. Estes condicionantes fan que sexa preciso agardar a futuras publicacións para ver como se concreta a viabilidade e as medidas hixiénico-sanitarias nestes formatos.

Como recoñecen ${ }^{19}$ dende a Asociación Galega de Orquestras (AGO), "unha festa popular, tal como se coñece en Galicia, é un evento no que se concentra moita xente, non só dunha vila ou dunha aldea, senón de toda unha comarca e, polo tanto, é a xuntanza máis social que hai en Galicia. Non se trata dun concerto onde a xente pode ir exclusivamente a mirar ou escoitar música, senón que o público participa e interactúa entre si, o que dificulta o establecemento das medidas de seguridade”. Fóra das cidades e principais vilas galegas, atopámonos ademais con que gran parte das festas e eventos culturais populares están promovidas por comisións de veciñas/os ou por asociacións culturais, polo tanto baseadas no voluntariado. Aínda que se se autorizan finalmente vexamos algunhas celebrarse, o risco a nivel de responsabilidade legal, a imposibilidade de ter recadado con tempo os cartos entre a veciñanza para contratacións e as dificultades técnicas para aplicar medidas probablemente fagan desistir á gran maioría.

Finalmente, hai que sinalar que no momento da publicación deste documento se veñen xa celebrando e anunciando numerosas actividades de rúa por toda Galicia ou incluso, en Santiago de Compostela, a primeira Feira do Libro en Europa despois da pandemia. Polo tanto, parece probable que moitas entidades aposten por desenvolver actividades no espazo público baixo un criterio de "pequenos formatos e público reducido".

Queda por tanto por ver cal será o grao de control e aplicación das recomendacións do Decreto-lei da nova normalidade, así como das normas posteriores que vaia establecendo a Xunta de Galicia e incluso os propios concellos. De novo, especialistas en prevención de riscos no sector cultural inciden na importancia da prudencia e da responsabilidade, especialmente desde eventos xa non só autorizados, senón incluso promovidos polas administracións públicas.

\footnotetext{
${ }^{19}$ O sector da música popular en Galicia perante a crise da COVID-19 consellodacultura.gal/publicacion.php?id=4369
} 


\section{A acción sociocultural}

Polo seu impacto económico e a presión das asociacións sectoriais, percíbense uns esforzos e unha regulación máis clara para reactivar a oferta de consumo cultural, especialmente de programacións artísticas. Pero non tanto para aquelas liñas de traballo máis ligadas á participación cultural e, polo tanto, baseadas no relacional e no encontro no espazo físico.

Isto inclúe a cancelación de actividades e visitas que permitían conectar os espazos culturais públicos coa comunidade educativa, sen un horizonte claro para poder retomar esta función didáctica. O impacto desta paralización da actividade tamén se estende á parte máis vulnerable dos axentes e creadores culturais, que teñen nas actividades formativas e actuacións en centros escolares unha vía de ingresos vital para a súa supervivencia. Aínda que xa se permiten actividades noutros espazos socioculturais de proximidade (centros cívicos, bibliotecas etc.), o certo é que nos meses de verán esta oferta adoita ser moito menor, máis nas actuais circunstancias.

O peche de espazos educativos, centros de día e outros recursos de conciliación fixo recaer sobre as familias todo o peso dos coidados de menores, adultos maiores e dependentes. Para estes últimos colectivos, considerados poboación de risco, a cancelación das programacións socioculturais tamén implicou a desaparición dun espazo de socialización esencial para o envellecemento activo e para evitar os efectos negativos da soidade non elixida.

A chegada da "nova normalidade" a Galicia non parece que vaia mudar a situación xa que, segundo o DOG do 13 de xuño, permanecerán pechados, mentres non se dite resolución da consellería competente que acorde a súa reapertura: os servizos e centros de atención á infancia, os espazos de mocidade, os centros sociocomunitarios de benestar, os servizos de conciliación de carácter grupal complementarios de programas de inclusión social, os centros de atención diúrna para persoas maiores ou persoas con discapacidade e as casas do maior.

Seguindo coas actividades de educación non formal, ocio educativo e tempo libre, na mesma data do 13 de xuño a propia Consellería de Política Social fixo público o documento ${ }^{20}$ que recolle as recomendacións e medidas para este ámbito. Coincide coa mesma semana na que se pecha este atípico curso escolar e, polo tanto, tamén ás portas da inminente apertura de campamentos de verán e actividades similares. De feito, fai sobre todo incidencia en medidas dirixidas a campamentos onde a mocidade tamén pase a noite.

${ }^{20}$ xuventude.xunta.es/component/k2/item/19162-recomendacions-e-medidas-parao-desenvolvemento-das-actividades-de-educacion-non-formal-ocio-educativo-etempo-libre-adaptadas-a-situacion-derivada-da-crise-sanitaria-do-covid-19 


\section{O coidado do tecido cultural do territorio}

Analizamos neste apartado a relación da xestión cultural pública co resto do ecosistema cultural do territorio, especialmente artistas, empresas e tecido asociativo. Centrámonos nas medidas máis a curto prazo, recuperando no seguinte bloque os debates e reflexións aprazadas.

A idea da responsabilidade dos gobernos locais como "actores de primeira orde na defensa e promoción dos dereitos culturais como dereitos fundamentais" impulsou a campaña \#Concelloscoacultura ${ }^{21}$ promovida pola AGPXC. Consistiu en remitir un modelo de carta a todos os concellos de Galicia coa que mostrasen o seu "compromiso coa cultura, ben re-programando, garantindo o orzamento anual en cultura que se tiña ata agora ou apostando pola cultura como ben de primeira necesidade”. As adhesións chegaron de entidades diversas como Santiago de Compostela, Pontevedra, Vilalba, Carral, A Pobra do Brollón, Malpica de Bergantiños ou Ribadeo.

A Federación Galega de Municipios e Provincias (FEGAMP) mantivo $\operatorname{contactos}^{22}$ coa Consellería de Cultura e Turismo para facilitar a reprogramación das actividades adiadas de xeito coordinado e evitando solapamentos. Os protocolos para que os concellos poidan aloxar os eventos coa garantía de máxima seguridade para os asistentes e a necesidade de cooperación entre administracións, incorporando tamén as deputacións provinciais, foron outras das propostas.

Tamén, xa o 13 de xuño, a FEGAMP cualificou de "positiva" a decisión da Xunta de permitir desde o 1 de xullo a celebración de festas, verbenas e outros eventos populares "de forma adaptada á COVID-19", aínda que reclamou a posta en marcha dun protocolo para estes eventos. Previamente xa solicitara instrucións acerca das medidas que seguir para poder organizar este tipo de eventos, xa que "é unha situación tan excepcional" que non pode deixarse só ao amparo da Lei de espectáculos, senón que require "instrucións claras" sobre "as medidas extraordinarias" que hai que adoptar.

Pola súa parte, a Federación Española de Municipios e Provinciais (FEMP) publicou unha "Proposta para a Reactivación Económica e Social da Administración Local" ${ }^{23}$ e un "Pacto para protexer a Cultura Local" ${ }^{24}$. O primeiro documento contén propostas relevantes para permitir aos concellos ser máis

\footnotetext{
${ }^{21}$ facebook.com/hashtag/concelloscoacultura

22 fegamp.gal/content/fegamp-traballa-na-reactivacion-do-sector-cultural-e-oturismo-tralo-confinamento-polo-covid

${ }^{23}$ femp.es/sites/default/files/multimedia/documento_aprobado_por_unanimidad_fe mp pilares_reactivacion_admon_local 22 mayo_2 0 .pdf

${ }^{24}$ femp.es/sites/default/files/multimedia/cultura.pdf
} 
efectivos na loita contra os efectos económicos e sociais da COVID-19 nos seus territorios. Por exemplo, facilitando o uso íntegro do depósito do Tesouro de Gastos Xerais xerados polas entidades locais (17.841 millóns de euros), flexibilizando parámetros como a estabilidade orzamentaria ou a regra de gasto.

Finalmente, a Comisión de Cultura da FEMP sinala que é necesario impulsar un plan específico de choque para recuperar e dinamizar o tecido cultural e artístico local. As medidas propostas teñen como obxectivo manter a actividade de todos os actores e axentes da cultura local e intensificar as súas interrelacións entre eles e con toda a comunidade. Por exemplo, unha política de "cancelación 0", que permite manter os contratos actuais con creadores, artistas e empresas auxiliares e servizos dos equipamentos culturais do municipio, e unha política de "pagamento do 100\%", que permite atender contratos existentes con axilidade para manter o emprego e permitir que os sectores culturais conserven liquidez.

\section{O sector profesional e empresarial}

O ámbito privado, dando por perdido o segundo trimestre do ano, centrou as primeiras semanas da crise en reivindicar accións de urxencia ante as administracións autonómica e central. En xeral, recibíronse de xeito positivo medidas de alivio importantes como os ERTE, axudas inéditas para autónomas/os e, aínda que con algo de demora, a flexibilización do acceso a estas medidas tendo en conta particularidades do sector, como a intermitencia no emprego. Tamén a paralización de prazos administrativos e adiamento de impostos.

Outras fórmulas, como as de financiamento bancario avalado polas administracións, resultaron menos empregadas, tanto pola perspectiva de endebedarse sen saber cando poder comezar a ingresar de novo, como pola pouca solvencia que as entidades bancarias outorgan á maioría do sector, máis aínda nesta situación de incerteza.

Xa volvendo ao ámbito local que nos ocupa neste documento, o eixe fundamental de traballo foi atopar mecanismos para adiar e non cancelar as contratacións previstas.

Neste sentido, cun sector público que conta cun déficit de investimento en equipos técnicos nas áreas de cultura municipais, moitas veces profesionais "todoterreo" que traballan en solitario, a necesidade de reforzar a confianza e a cooperación entre o sector público e o privado sinalábase nos debates como esencial para superar o bloqueo da actividade. Isto fundaméntase na dificultade inicial para atopar mecanismos dentro dos procedementos de contratación pública e na falta de certezas sobre que actividades podían ir realizándose ao 
longo do tempo, dentro das xenéricas recomendacións ou limitacións que ían marcando as autoridades sanitarias.

En xeral, valórase positivamente a reacción de complicidade públicoprivada e a aprendizaxe conxunta para adaptarse ao escenario dos vindeiros meses, tanto no plano administrativo como no operativo. Esta complicidade tamén parece importante para defender os orzamentos públicos en cultura, que poidan ser ou considerarse máis prioritarios para outras áreas.

Por outra parte, unha das debilidades que se apuntan habitualmente no debe do sector profesional galego, a pequena dimensión de empresas e formatos, pode ser neste caso unha vantaxe para a supervivencia nos vindeiros meses. O sector público, que tampouco vai poder contar con artistas internacionais nin desenvolver grandes eventos, debería apostar por este tecido máis próximo para manter a súa actividade durante o verán.

Como diciamos, o principal mecanismo de apoio ao sector que se pon en marcha desde os concellos é reactivar a actividade o antes posible e intentar manter os compromisos adiados do segundo trimestre, especialmente de programación artística. Neste sentido, é importante sinalar que gran parte da oferta escénica dos concellos cóbrese a través de distintas redes promovidas por outras entidades estatais, autonómicas e provinciais. Coñecemos a continuación algunhas medidas que se foron desenvolvendo nestas redes.

O INAEM ampliou até marzo de 2021 o Programa PLATEA destinado a fomentar a circulación estatal de espectáculos de teatro, música, danza e circo.

A Rede Galega de Teatros e Auditorios (RGTA) da AGADIC, da que forman parte 40 concellos galegos, adaptouse de cara ao segundo semestre de actividade cunha serie de medidas que flexibilizan a normativa deste circuíto de índole profesional, coa finalidade de recuperar todas as funcións que tiveron que ser suspendidas durante o estado de alarma e deseñar unha nova carteleira ata decembro. Deste xeito, por exemplo, para facilitar a programación permitiranse as actuacións ao aire libre durante os meses de verán, en escenarios pechados diferentes aos adscritos á Rede ou como parte de festivais, mostras ou certames organizados polas distintas localidades. A nova convocatoria queda reservada a compañías de teatro e grupos musicais galegos, xa que para as formacións procedentes de fóra de Galicia prorrógase a selección que fora realizada para o primeiro semestre de 2020.

A Rede Cultural da Deputación da Coruña ampliou tamén o prazo para a contratación de espectáculos, mantendo o orzamento destinado a programación dos concellos a través dos programas Escena Ao Vivo, Lingua a Escena e Visións!, que repercuten directamente no sector profesional das artes escénicas, música, maxia e narración oral. Neste caso os concellos poden ademais estender a realización de espectáculos ata o 31 de marzo de 2021. 
Pola súa banda, a programación da Rede de Auditorios Provincial (reaOU), integrada por 36 concellos e impulsada pola Deputación de Ourense, apostou pola programación exclusiva de artistas da provincia e que esta poida realizarse a partir do 1 de xullo.

No caso dos festivais de artes escénicas en Galicia, vemos que moitos deles están tamén impulsados por concellos. Aínda que a asociación que agrupa os festivais de artes escénicas de Galicia (AFEARTE) reclamou recentemente que o prazo de execución das axudas da Axencia Galega de Industrias Culturais (AGADIC) puidesen contemplar máis alá do exercicio económico de 2020, finalmente manteranse os prazos de execución iniciais. Aumenta o requisito de presenza de compañías galegas ou maioritariamente compostas por artistas que desenvolvan principalmente a súa actividade profesional en Galicia, que neste caso deberá ser de ata o 60\%, cando na anterior convocatoria de 2019 era dun 20\%. Tamén se dá un cambio na rebaixa dun mínimo do 50\% (2019) ao 30\% (2020) das representacións escénicas que teñen que ser con entradas de pagamento, excepto os festivais de rúa e, por vez primeira, contempla do mesmo xeito os celebrados en liña, que tamén quedan exentos desta porcentaxe. En calquera caso, esta liña de subvencións convócase en xuño de 2020 para festivais cuxa realización tivese xa lugar ou vaian celebrarse entre o pasado 1 de novembro do ano 2019 e o 31 de outubro do ano 2020. Calquera re-formulación nas súas programacións suporá funcionar con prazos moi axustados, especialmente para eventos que habitualmente traballan con moita antelación no peche dos seus programas.

Noutra liña de traballo complementaria, algunhas administracións apostaron por convocatorias abertas de contratación para apoiar a supervivencia do sector. Algúns exemplos son o Fondo de Proxectos Culturais Xacobeo $2021^{25}$ ou o Plan de Dinamización Cultural ${ }^{26}$ do Concello da Coruña. Nestes casos, dáselle prioridade a garantir un mínimo de ingresos a moitos axentes culturais, aínda sen ter a certeza inicial de onde e como poderán programarse as actividades.

É de sinalar a preocupación de parte do sector privado pola posible saturación de oferta no outono ou a falta de certezas sobre cando e onde van a localizarse futuras programacións gratuítas promovidas polas distintas administracións. Entramos aquí tamén nun debate vello, sobre as dificultades de promover propostas de iniciativa privada, dependente da venda de entradas e ingresos propios, que en calquera momento poden verse contra-programados por iniciativas públicas de balde. Aínda que a maioría dos festivais e eventos

\footnotetext{
${ }^{25}$ lingua.gal/a-secretaria-xeral/convocatorias/_/axuda/convocatoria_0049/fondoproxectos-culturais-xacobeo-2021

${ }^{26}$ coruna.gal/web/gl/actualidade/novas/nova/abriuse-a-convocatoria-do-plan-dedinamizacion-cultural-da-cidade-por-un-importe-de-200-000euros/suceso/1453734539308
} 
deste verán se viron obrigados a adiar as súas citas ata 2021, quen aposte por reprogramar para o que queda de 2020 farao baixo a dobre ameaza da volta de medidas restritivas por rebrotes e desta eventual competencia de oferta gratuíta.

Outro colectivo moi afectado do tecido privado é o que reúne a Asociación Galega de Salas de Música ao Vivo (Clubtura), espazos de programación privada que xa levaban denunciando falta de apoio por parte das administracións. E, sobre todo, de comprensión sobre o seu importante labor cultural e de apoio a artistas locais e emerxentes. Coas medidas que seguir nesta "nova normalidade" para recintos pechados, como a limitación de capacidade ou a obrigatoriedade de contar con asentos, anuncian tamén que será moi difícil retomar a súa actividade.

\section{A cultura popular, o tecido asociativo e amador}

Gran parte da actividade cultural do País, tamén importantes eventos e programacións socioculturais, está sustentada polo tecido asociativo e amador. Fóra do foco mediático, sen organizacións sectoriais que defendan os seus intereses específicos e cunha estrutura financeira e profesional aínda máis feble que o sector empresarial, a supervivencia de moitas iniciativas pode perigar co cesamento de actividade e as dificultades para adoptar as medidas para retomala.

Sobre todo en contornas rurais, a poboación que participa é de idade avanzada e xa que logo grupo de risco. $\mathrm{O}$ medo ao contaxio polo tanto pode ser máis elevado. Ademais, ao tratarse de iniciativas activistas e sen remuneración económica, as persoas implicadas nas asociacións poden non querer asumir a responsabilidade derivada de organizar eventos ou actividades no contexto actual.

Dende os concellos e os seus equipos técnicos, apúntase á necesidade de reforzar o labor de acompañamento e de apoio, especialmente arredor dos protocolos e medidas de seguridade. Isto pode vir acompañado de apoio económico ou directamente material, cos medios precisos para poder retomar a actividade segundo as normativas vixentes.

Outro problema estrutural, relevante neste momento, é o modelo produtivista que se adoptou dende moitas entidades sociais, cun exceso de programación. Esta lóxica máis próxima á de mercado de empresas de lecer, tempo libre ou formación artística e creativa, así como incluso á de eventos profesionais, fai que a supervivencia de moitos proxectos, incluso históricos, dependa ano a ano de ingresos por cotas por actividade ou de modelos ligados ao consumo dos públicos como a venda de entradas, barras, material promocional etc. 
Polo tanto, igual que no ámbito privado, parece indicado flexibilizar os apoios económicos dirixidos a sustentar a propia supervivencia das entidades, desligándoas de criterios baseados no volume de actividades ou número de asistentes, e reforzando criterios máis cualitativos.

En calquera caso, dada a diversidade de situacións deste colectivo, unha medida xeral é fortalecer o diálogo e a colaboración, podendo dar tamén espazo e recursos na re-programación forzada das propias actividades municipais, especialmente de festas, a este tecido local amador.

\section{Novos formatos}

Aínda que inicialmente se prevía que as limitacións impostas pola pandemia xerarían un bo número de formatos innovadores, especialmente de pequeno tamaño, nesta fase de "nova normalidade" percíbese máis ben unha mera adaptación técnica no que respecta a capacidades e distancias de seguridade. Queda por ver como se irá resolvendo a incómoda imaxe inicial de patios de butacas moi baleiros, con público enmascarado e disperso. Probablemente vexamos máis propostas para mellorar o confort e o ánimo do público que grandes adaptacións en escena.

De calquera xeito, especialmente durante a fase de desescalada si que se observaron iniciativas interesantes. En moitos casos con intermediación dixital, como veremos no seguinte apartado, pero tamén presenciais.

Un exemplo destes últimos serían os “concertos verticais” de rúa, que a empresa Culturactiva levou a modo de pasarrúas por varios concellos, co público nas ventás e balcóns. Tamén iniciativas de pequeno formato como "Muralleando" con artistas locais ao longo da muralla lucense ou a recuperación dos auto-cines.

\section{A contorna dixital}

Coa poboación recluída nas súas casas, as fiestras dixitais abríronse ${ }^{27}$ nun primeiro momento desde unha perspectiva xenerosa por parte de artistas e empresas, para facer máis levadío o confinamento. A retransmisión en liña de

\footnotetext{
${ }^{27}$ Artigos que recompilan algunhas das iniciativas máis relevantes durante o confinamento: culturagalega.gal/noticia.php?id=30867 |

culturagalega.gal/noticia.php?id=30878 $\mid$ culturagalega.gal/noticia.php?id=30881 | culturagalega.gal/noticia.php?id=30883 | culturagalega.gal/noticia.php?id=30937 | $\underline{\text { mediaciondixital.bencuriosa.gal | nosdiario.gal/articulo/cultura/cultura-galega-pasar- }}$ corentena/20200316184842093128.html
} 
concertos, espectáculos escénicos e contacontos, así como ciclos audiovisuais foron habituais, especialmente os dirixidos a familias.

As administracións locais responderon tamén levando contidos á rede, improvisando cos recursos e competencias que cada área tiña á man. Analizando as propostas, aínda queda un longo camiño na transformación dixital dos concellos. Pero esta resposta de proximidade e a alta participación do público, como no \#OSalónVirtual ${ }^{28}$ do Salón do Libro Infantil e Xuvenil de Pontevedra, deixou ver que, sen poder substituír a experiencia presencial, si que é un xeito de chegar a públicos máis amplos, polo que debera ser unha vía complementaria que permaneza no futuro. Incluso no máis inmediato para compensar a limitación de cabida.

O que tamén se fixo evidente é que non era sostible para o sector privado ofrecer eternamente contidos gratuítos. Algunhas iniciativas municipais recibiron forte contestación por non contemplar remuneración, pero outros concellos déronse conta de que era tempo de devolver a xenerosidade inicial do sector privado mantendo compromisos e buscando alternativas.

Así, en canto a desescalada o fixo posible, a retransmisión en liña de espectáculos programados nos espazos públicos permitiu non só manter a contratación de artistas, senón tamén dos equipos técnicos, un dos gremios menos visibles e con difíciles perspectivas nestes tempos. Un exemplo pode ser o Concello de Vilalba, que programou xa a finais de abril concertos de bandas locais, pero tamén circo ou maxia, tanto de artistas galegos como de fóra. Entre outros sumáronse en maio tamén Vilagarcía de Arousa, cunha coidada produción en streaming para as súas Festas de Santa Rita, ou o Concello de Lugo, que con motivo do Día de Europa programou xunto á empresa IdeaRock o concerto en liña da lucense Laura LaMontagne e o artista asturiano Rodrigo Cuevas. Todos eles contidos dispoñibles só en directo ou por tempo limitado, pero gratuítos.

Queda por ver se poderán consolidarse propostas de pagamento en liña como a de 'Somos Criminais' ${ }^{29}$, con Carlos Blanco e Touriñán, que reuniu a dez mil persoas que nos días anteriores mercaran 3350 accesos a 5 euros, un por fogar. O impacto entre a comunidade emigrante, con conexións desde 47 países, reforza a idea de que esta vía permite chegar a públicos interesados por contidos galegos, pero que non necesariamente poden acudir ás actividades presenciais. Neste caso tratábase dunha iniciativa privada, polo que para programacións financiadas con fondos públicos queda tamén por ver o sentido deste modelo de emisión en liña, sexa gratuíto ou non, máis aló da promoción de contidos ou artistas locais.

\footnotetext{
${ }^{28}$ salondolibro.gal/salon-virtual/

${ }^{29}$ culturagalega.gal/noticia.php?id $=31219$
} 
Dende a perspectiva dos espazos culturais, a imaxinación e a mediación tecnolóxica fixeron posible continuar con liñas de traballo como visitas guiadas a museos, cursos, clubs de lectura en bibliotecas ou iniciativas participativas para todas as idades. Bos exemplos serían a Rede Museística Provincial de Lugo $^{30}$ ou as Bibliotecas Municipais da Coruña ${ }^{31}$.

Outro aspecto relevante é como moita xente accedeu por primeira vez ao uso de canles de comunicación dixital e ás lóxicas propias desta contorna. Así, vimos como profesionais da cultura, pero tamén xente anónima, se apropiaron de ferramentas dixitais, perderon o medo a experimentar con elas e compartiron en círculos privados ou en redes sociais numerosos contidos. Esta cultura popular contemporánea que nutre as redes, onde a calidade do produto final non é sempre o máis relevante, fala moitas veces de nós, do territorio, e tamén é un sinal de participación cultural activa. Algunhas iniciativas buscaron a complicidade de veciñas e veciños para facer posibles procesos colectivos en redes, a través de cancelos e unhas pautas mínimas. Sen dúbida, as propostas para manter viva a Festa dos Maios $^{32}$ son unha das mellores mostras, promovidas por colectivos veciñais ou por concellos, como Ferrol ou Narón.

Aproveitando este acceso por primeira vez de moitas persoas maiores, que durante máis tempo terán aínda pechados espazos de socialización, apúntase tamén a necesidade de seguir explorando o traballo en liña con eles, tamén a formación, empregando ferramentas accesibles como videotitoriais por canles de mensaxaría ou videochamadas.

Finalmente, quedan tamén dúas reflexións bastante compartidas. Por unha parte o reto das fendas dixitais, non só xeracionais senón tamén socioeconómicas, que se fixeron máis evidentes neste momento. Por outra, como esta "experimentación á forza" fixo ver a entidades de todo tipo, públicas e privadas, as súas carencias pero tamén as oportunidades que ofrece o ámbito dixital.

${ }^{30}$ redemuseisticalugo.org/documentos.asp?mat $=9 \& i d=3312$

${ }^{31}$ coruna.gal/bibliotecas/gl

${ }^{32}$ bencuriosa.gal/mediaciondixital/a-festa-dos-maios/ 


\section{O camiño cara á nova normalidade | recursos para ampliar}

DOCUMENTOS DE TRABALLO CCG

\section{9 a 12 de xuño de 2020 | Estratexias e ferramentas}

Nesta terceira e última entrega do ciclo de conversas en liña "Xestión e políticas culturais nos concellos | Retos ante a COVID-19”, recolleuse unha serie de doce micro-entrevistas a axentes culturais do ámbito público e privado, que foron publicadas en catro bloques diarios dende $\mathrm{o}$ martes 9 ao venres 12 de xuño.

Ademais de coñecer os puntos de partida e as aprendizaxes adquiridas durante as semanas de confinamento e desescalada, recóllense propostas de estratexias e ferramentas para reactivar as programacións, explorar novos formatos, abordar a transformación dixital e coidar o ecosistema cultural do territorio, especialmente o máis próximo, coa perspectiva do futuro máis inmediato.

- O camiño da nova normalidade

o Julio Gómez (codirector de Sinsal)

o Xosé Manuel Blanco (presidente da Asociación Galega de Empresas Musicais | Nalgures Producións) - 8'25"

o Encarna Lago (xerente da Rede Museística Provincial de Lugo | membro da Comisión) - 22’06”

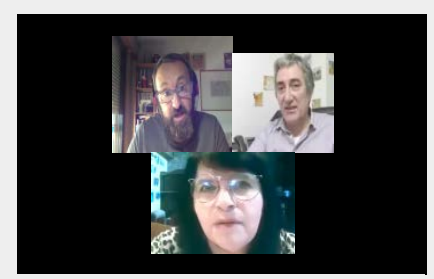

over vídeo

Neste momento de reactivación da actividade e de reapertura dos espazos culturais, achegámonos ás claves para poder facelo dende as dúas premisas principais que marcarán esta nova etapa: garantir a seguridade e xerar confianza no público. Abarcamos a situación en eventos ao vivo, tanto ao aire libre como en recintos pechados, e tamén a perspectiva dos espazos expositivos e museísticos.

Ademais do enfoque da oferta de consumo cultural, tanto de programacións artísticas como de xestión de visitas a espazos culturais, tamén nos interesamos por aquelas liñas de traballo máis ligadas á participación social e, polo tanto, baseadas no relacional e no encontro no espazo físico. Outro elemento de análise é como as urxencias na reactivación da actividade poidan estar desprazando outros retos transversais, de grande importancia ata a chegada da
Sdetalle do evento onota de prensa 
COVID-19, como a sustentabilidade, a accesibilidade, a inclusión ou a participación comunitaria, especialmente no espazo público.

- O coidado do tecido cultural do territorio

o Dani Cánovas (animador sociocultural no Padroado da Cultura de Narón)

o Emi Candal (socia de Urdime e responsable da Sectorial de Cultura de Unión de Coperativas Espazocoop) - 8'37"'

o Fran G. Quiroga (investigador e axente cultural independente) - 18'00"

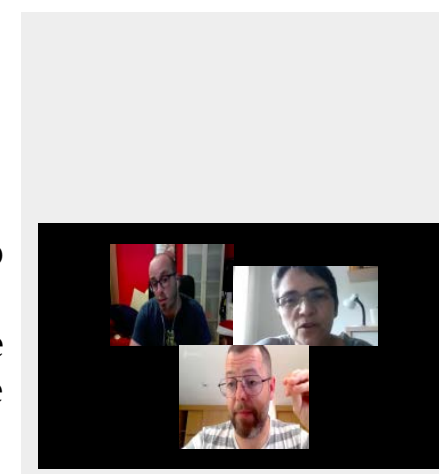

over vídeo
DOCUMENTOS DE TRABALLO CCG

Unha das maiores preocupacións do momento actual na Cultura é o impacto da COVID-19 no presente e futuro do fráxil sector privado. Aínda que o primeiro que se nos veña á cabeza sexa o ámbito empresarial e artístico, o certo é que gran parte da actividade cultural do País, tamén importantes eventos e programacións socioculturais, está sustentada polo tecido asociativo e amador. Fóra do foco mediático, sen organizacións sectoriais que defendan os seus intereses específicos e cunha estrutura financeira e profesional aínda máis febre que o sector profesional, a supervivencia de moitas iniciativas pode perigar co cesamento de actividade e as dificultades para aplicar os protocolos. Preguntámonos como pode orientarse o traballo municipal en cultura para protexer este tecido.

Por outra parte, grazas á súa maior organización, o ámbito profesional e empresarial logrou unha certa visibilidade das súas necesidades e demandas, especialmente nas disciplinas máis vinculadas ao directo, como son as programacións artísticas escénicas e musicais. Coñeceremos como se valora a evolución nestes meses da relación cos equipos municipais de cultura, así como algunhas propostas para seguir xerando espazos de cooperación, aprendizaxe e axuda mutua. Finalmente, tamén nos achegamos a outros enfoques e disciplinas culturais menos visibles, onde creadoras e investigadoras xa viñan traballando fóra das lóxicas do mercado, xeralmente en condicións intermitentes e precarias.

- Os novos formatos

o Vanesa Siso (concelleira de Cultura, Comunicación e Igualdade no Concello de Vilalba)

o Nacho Fungueiriño (socio de Culturactiva) $-5,45$ ”

o Marcos López (responsable de Viva Lugo) $15^{\prime} 04 ”$

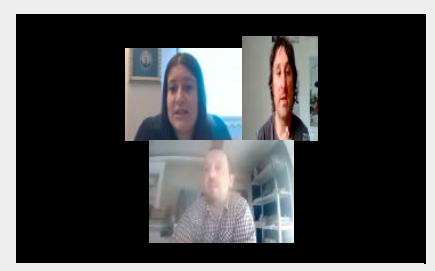

over vídeo 
A situación excepcional do confinamento fixo agromar iniciativas socioculturais e artísticas que experimentaron novos xeitos de facer chegar cultura, virtualmente, á poboación confinada. Moitas entidades víronse obrigadas a explorar, algunhas por primeira vez, as posibilidades do ámbito dixital. Tamén, xa na posterior "desescalada”, xorden novos formatos adaptados ás limitacións de cada fase.

Preguntamos a tres axentes do ámbito público, privado e da comunicación cultural, polas aprendizaxes adquiridas e por cales destas novas prácticas e ferramentas pensan que poden perdurar na "nova normalidade". Finalmente, abordamos como poder garantir no ámbito dixital formatos de contratación sostibles economicamente para profesionais e artistas.

\section{- A transformación dixital}

o Carmen Suárez (dinamizadora TIC en San Sadurniño)

o Ruth Sousa (socia e responsable de comunicación en BenCuriosa) - 12'04"

o María Yáñez (directora de Vinte) - 19'48"

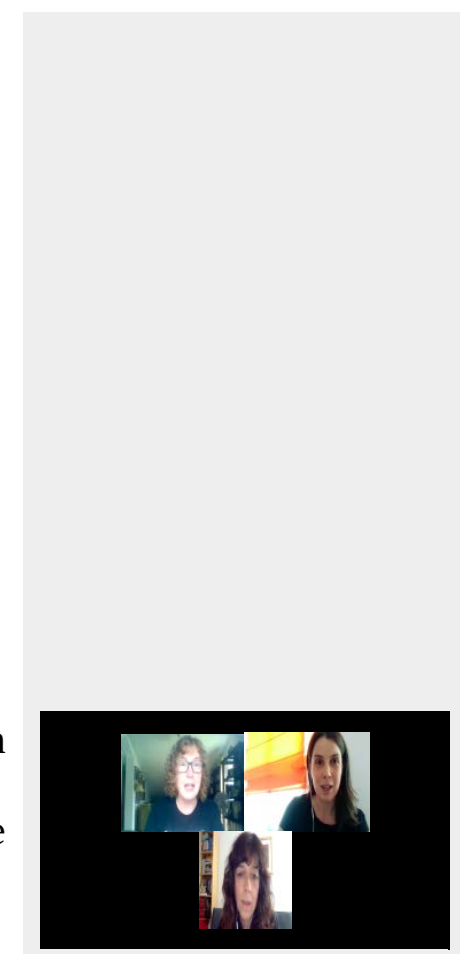

Un dos aspectos clave nestes meses foi observar o grao de madurez do proceso de transformación dixital no que estamos inmersos como sociedade. Tanto as oportunidades como as carencias visibilizáronse de xeito nítido e sobre elas conversamos nesta entrega.

Primeiro achegámonos ao labor de dinamización TIC, unha figura moi vinculada ata agora coa alfabetización dixital de persoas maiores, pero que cada vez resulta de maior importancia en calquera estratexia sociocultural integral dunha Administración pública. As necesidades de capacitación e inclusión para reducir as fendas existentes son claramente interxeracionais. E sobre elas debemos traballar para que todas poidamos exercer unha cidadanía dixital plena, sen deixar a ninguén atrás.

Con este obxectivo, da inclusión dixital, analizamos as grandes oportunidades que nos ofrece o traballo en cultura, co patrimonio inmaterial, coa creatividade ou con temas sociais próximos. E de como facelo a través dunha estratexia de dinamización e mediación dixital adecuada á entidade e ao seu territorio.

Así, as posibilidades de promover narrativas sobre a realidade máis próxima e de identificar e acompañar as que a nosa veciñanza xera de xeito espontáneo na Rede, é outro dos retos que abordar. Podemos facelo da man das novas xeracións creadoras que xa están a desenvolver contidos coas linguaxes e ferramentas dixitais, pero tamén cun labor de escoita, selección e arquivo activo. 
Finalmente, pechamos a conversa incidindo na importancia de contar xa coa contorna dixital como un espazo de acción sociocultural ineludible, no que poder garantir a participación e a existencia dunha visión propia dende a nosa realidade. Algo imprescindible dentro da inmensa, pero cada vez máis concentrada, unificada e globalizada, oferta de contidos dixitais audiovisuais.

\section{OUTROS RECURSOS}

\section{PARA A REACTIVACIÓN DE PROGRAMACIÓNS E ESPAZOS CULTURAIS}

- A previsión de desescalada cultural. Artigo de culturagalega.gal, que inclúe a recompilación deste tema noutros medios de comunicación galegos (29 de abril): http://culturagalega.gal/noticia.php?id=31044

- Medidas que marcan a transición cara á "nova normalidade" recollidas no Real decreto-lei 21/2020. BOE (10 de xuño): boe.es/diario_boe/txt.php?id=BOE-A-2020-5895

- Medidas de prevención necesarias para facer fronte á crise sanitaria ocasionada pola COVID-19, unha vez superada a fase III do Plan para a transición cara a unha nova normalidade. DOG (13 de xuño) xunta.gal/dog/Publicados/2020/20200613/AnuncioC3K1-120620-1_gl.html

- Protocolo de medidas operativas y sanitarias COVID-19 para la reactivación de los espacios escénicos. Red Española de Teatros, Auditorios, Festivales y Circuítos de Titularidad Pública. (26 de maio): redescena.net/redaccion/2020/05/LARED_COVID.pdf

- Saúde laboral nos servizos e producións de eventos e espectáculos ante o coronavirus. Instituto de Seguridade e Saúde Laboral de Galicia (ISSGA) en colaboración coa Asociación Galega de Empresas Musicais (AGEM) e a Asociación de Empresas Tecnolóxicas e Servizos Audiovisuais de Galicia (AGATEC) (Última actualización 03 de xuño): issga.xunta.gal/portal/contido/actualidade/novas/nova_1279.html

- Guía de buenas prácticas para el reinicio de la actividad escénica y musical en España. Instituto Nacional de las Artes Escénicas y de la Música (INAEM) (12 de xuño):

culturaydeporte.gob.es/cultura/artesescenicas/contenedora-noticiasprensa/a2020/junio/guia-buenas-praticas-covid.html

- El patrimonio cultural y los museos frente a la crisis del COVID-19. Consejo Internacional de Monumentos y Sitios (ICOMOS): icomos.es/covid19

- Museos y sitios patrimoniales. Medidas para la reducción de contagio por el coronavirus SARSCoV-2. Directrices y recomendaciones. Instituto para la Calidad Turística Española (ICTE) (maio): femp.femp.es/files/566-2740archivo/Museos-y-sitios-patrimoniales-COVID.pdf 
- Pautas para la gestión, conservación y disfrute público del patrimonio cultural en la desescalada de la crisis sanitaria. Instituto de Patrimonio Cultural de España (IPCE) (01 de xuño):

culturaydeporte.gob.es/actualidad/2020/06/200601-medidaspatrimonio.html

- Recursos clave para a resposta da biblioteca ante a pandemia de coronavirus. Federación Internacional de Asociacións de Bibliotecarios e Bibliotecas (IFLA) (última actualización 05 de xuño): ifla.org/ES/node/92983

- Recomendacións e medidas para o desenvolvemento das actividades de educación non formal, ocio educativo e tempo libre adaptadas á situación derivada da crise sanitaria da Covid-19. Consellería de Política Social (13 de xuño): xuventude.xunta.es/component/k2/item/19162recomendacions-e-medidas-para-o-desenvolvemento-das-actividades-deeducacion-non-formal-ocio-educativo-e-tempo-libre-adaptadas-a-situacionderivada-da-crise-sanitaria-do-covid-19

- Pacto para proteger la cultura local. Federación Española de Municipios y Provincias (FEMP) (22 de maio): femp.es/sites/default/files/multimedia/cultura.pdf 


\section{Os debates aprazados}

Como indicamos ao inicio do documento, nos primeiros momentos agromaron un número excepcional de espazos de reflexión, cunha alta participación de axentes culturais. Nesta pausa única, ademais de buscar solucións para as ameazas máis inmediatas sobre o sector, puideron poñerse en común moitas das debilidades e fortalezas estruturais do noso tecido cultural.

Despois do parón, entramos xa en maio nunha dinámica de sobreesforzo das profesionais para a reapertura de espazos e a reactivación de programacións o antes posible. Houbo que poñerse a adaptar contratacións e orzamentos pero tamén espazos e actividades ás medidas hixiénico-sanitarias de cada fase, que se ían coñecendo ademais con moi pouca marxe de tempo. Este contexto alongarase durante todo o verán, no que se está a planificar o seguinte curso baixo a sombra de incertezas sobre a evolución da situación sanitaria, especialmente coa chegada do outono.

É entendible, polo tanto, que moitos debates menos urxentes quedasen aprazados. Pero non por iso deberían quedar esquecidos, xa que reflicten a fraxilidade estrutural do noso ecosistema cultural ante calquera crise. A eles adicamos este terceiro e último bloque.

\section{Quen somos?}

Recuperando reflexións previas ${ }^{33}$, estamos ante unha profesión recente, polo menos na normalización da súa denominación como "xestor/a cultural” e cunhas funcións no ámbito público que foron adaptándose nos últimos corenta anos segundo se ían creando e consolidando novos servizos e equipamentos. Así, especialmente en concellos pequenos, é moi habitual atopar "técnicas/os de cultura" que se foron encargando ao longo do tempo, incluso simultaneamente, da xestión e dinamización de áreas tan diversas como bibliotecas, mocidade, maiores, deportes, normalización lingüística, aulas de alfabetización dixital, festas etc., ademais das que deberían ser propias, como son o deseño, planificación e coordinación de programas e proxectos culturais.

\footnotetext{
${ }^{33}$ LAGO, S. e M. LORENZO (coords.) (2019): A xestión cultural en Galicia. Unha visión panorámica e actual, Santiago de Compostela, Editorial Andavira. |

usc.xestioncultural.com/publicacions
} 
Aínda que nos últimos anos existe unha tendencia cara á especialización nestas últimas tarefas, esta evolución tan recente implica que, a día de hoxe, atopemos na Administración pública galega un mapa de profesionais con competencias e funcións similares pero que, dependendo do momento da súa incorporación e das súas responsabilidades iniciais, teñan un nivel formativo, categorías salariais e condicións laborais moi desiguais. Outra consecuencia é a falta de organigramas claros en áreas e servizos de cultura, especialmente nos que foron acumulando servizos e equipamentos construídos sen unha planificación e proxecto de acción cultural previo.

Dende a AGPXC estase a traballar nunha posible "Descrición dos postos de traballo nos departamentos de cultura da administración local" ${ }^{34}$, cun primeiro documento publicado a comezos deste 2020. Nel sinálanse os principais retos laborais xa que se trata dun "sector que carece de regulación propia en canto á fixación das condicións de traballo e as xornadas laborais e que esixe unha loita contra a precariedade laboral e un recoñecemento profesional. Ao carecer dun convenio laboral sectorial, complicado de elaborar, pois moitos dos profesionais da xestión cultural traballan no sector público, co que están suxeitos a convenios das súas propias administracións, nos que non se recollen estas casuísticas especiais, sería máis adecuado establecer unhas recomendacións en canto á fixación das xornadas de traballo, a compensación das horas extraordinarias, o dereito á desconexión e descanso, a fixación das responsabilidades e funcións dos diferentes perfís profesionais, a necesidade de formación continua no posto de traballo, a asistencia a feiras profesionais ou a estreas ou visionados de espectáculos, recomendacións que se deberían facer chegar á FEMP, ás Federacións territoriais e aos sindicatos para que trasladen ás Administracións Públicas, de maneira que se poña en valor a profesión e se vaian unificando e homoxeneizando as funcións dos postos de traballo á hora de elaborar as bases da ofertas públicas de emprego.”

Queda por tanto aínda moito camiño por diante: lograr consensos profesionais máis amplos, construír con eles capacidade real de negociación sectorial ante as administracións e, finalmente, obrigar a unha maior planificación e execución de políticas culturais que os teñan presentes.

\section{Para quen traballamos?}

Probablemente sexa a pregunta máis repetida para cuestionar parte do actual modelo de traballo dentro da xestión e políticas culturais nos concellos galegos.

A prioridade dada á reactivación de programacións, como vimos, ten toda a lóxica como medida efectiva, a curto prazo, para intentar protexer unha

\footnotetext{
${ }^{34}$ xestoresculturais.gal/wp-content/uploads/2020/02/Descrici\%C3\%B3n-perfilprofesional-na-administraci\%C3\%B3n-local.pdf
} 
gran parte do tecido privado. Especialmente o ligado á creación artística e a súa distribución e exhibición, que non ten un plan B de supervivencia. Neste caso excepcional non se trata de avaliar a posible resposta dos públicos, porque os obxectivos son outros, pero si que é un exemplo de liña de traballo centrada na oferta e non nunha demanda real. E isto xa non é tan excepcional.

Sinálase tamén que, no día a día, o persoal técnico, asesor ou político mantén un contacto constante con empresas culturais, técnicas e ás veces artistas, pero non sempre ten tempo para os seus destinatarios reais. E viceversa, como o sector privado deseña algunhas propostas pensando só na venda ao cliente institucional. Polo medio, atopamos eivas estruturais que perpetúan esta situación, como os limitados equipos de traballo municipais, pero tamén a ausencia de avaliación, estudos de públicos ou xestión de datos das audiencias. Evidentemente isto non é así sempre pero, como diciamos, trátase de cuestións lanzadas para reflexionar e mellorar a práctica profesional.

Outro cuestionamento clave é se na actualidade a acción cultural pública pode seguir limitándose a programas e infraestruturas centradas en ofertar produtos culturais para espectadores pasivos. Ou se debería ter máis peso na xestión e políticas culturais a participación, a escoita activa e un labor máis facilitador que dirixista sobre a creación cultural. Un modelo coas "persoas no centro", promovendo espazos para a experimentación e a innovación, onde poidan xurdir proxectos que respondan aos propios intereses e necesidades das e dos participantes. En definitiva, o aínda vixente debate sobre o equilibrio entre democratización e democracia cultural.

\section{Unha idea máis ampla de ecosistema cultural e creativo}

Recuperando a idea previa de "coidado" do tecido cultural dun territorio, apúntase tamén á necesidade de ampliar o foco e ser conscientes da pluralidade de axentes culturais e creativos que operan no noso territorio. Ter máis en conta a dimensión amadora, pero tamén a quen opera e crea ás marxes do que se pode entender de xeito máis clásico como "industria cultural”. Ou, incluso, simplemente colaborar máis con outros elos da cadea de valor desta, esenciais na dinamización cultural dun territorio, como poden ser as salas de concertos ou as librarías.

Unha ferramenta interesante para achegarse á complexidade e diversidade actual de sectores e subsectores, enlaces na cadea de valor e tipoloxía de axentes implicados así como ás características dos seus impactos é a metodoloxía de mapeado "Kultursistema" 35 . Un dos seus promotores, Roberto

\footnotetext{
${ }^{35}$ KULTURSISTEMA é un proxecto desenvolvido pola asociación profesional vasca KARRASKAN, adicada ao fomento da innovación en cultura e á cultura de innovación. Foi coordinado por Roberto Gómez de la Iglesia, de Conexiones improbables, e Ricardo Antón Troyas, de ColaBoraBora. | karraskan.org/es/kultursistema/
} 
Gómez de la Iglesia, insiste tamén na idea de que "a economía creativa non só fala de sectores culturais e creativos, senón tamén de como a partir destes podemos facer outros ámbitos económicos e sociais máis creativos e innovadores. Como somos capaces de facer máis creativos os territorios, é dicir, a súa xente”.

Pola súa banda Lluís Bonet i Agustí indica que "máis aló dos recursos económicos, saber escoitar, acompañar e aconsellar de xeito asertivo son valores clave, especialmente importantes en momentos de incerteza como o de hoxe. Debe facerse, non obstante, co máximo respecto, coraxe e empatía posible. Acompañar non debe ser incompatible con tomar decisións difíciles e valentes, como priorizar recursos cara a aquelas actividades máis necesarias para garantir unha vida cultural plena unha vez finalizada a pandemia. Non obstante, a pesar de saber que moitas organizacións e proxectos terán que pechar, con efectos graves na supervivencia económica de moitos profesionais, non é posible condenar a ninguén desde o principio sen estudar os distintos graos de resiliencia de cada organización. E iso pasa pola proximidade; é dicir, polo principio de subsidiariedade tan repetido pero pouco aplicado. Canto máis preto dun proxecto, os seus profesionais e a comunidade de referencia, máis doado é estimar potenciais e necesidades, e así adaptar localmente a gama de instrumentos políticos, financeiros e de apoio dispoñibles. Compartir información sobre estratexias e instrumentos a nivel nacional e internacional é extremadamente útil, pero a súa adaptación debe ser rexional e local”.

Finalmente, vemos importante recuperar tamén outra reflexión amplamente repetida: moitos axentes culturais desenvolven a súa actividade nunha situación precaria. Para afondar nesta cuestión e as súas implicacións socioeconómicas, apúntanse referencias como Marina Garcés ou Jaron Rowan, pero resulta ineludible citar a Remedios Zafra, autora de El entusiasmo (Anagrama, 2017): “A precariedade é unha das formas máis habituais que adquire a desigualdade no capitalismo e é importante porque hoxe caracteriza os modos predominantes de traballo nun mundo conectado. É tan habitual que tende a pasar desapercibida. E paréceme que isto ocorre por varias razóns, entre outras: a precariedade no traballo creativo camúflase con altas doses de motivación e voluntarismo; en ocasións recibe pagos inmateriais ou simbólicos que fan sentir aos traballadores que xa tiveron unha ganancia -aínda que sexa un mero certificado ou unha maior visibilidade-; reforzan a tradición de que a creación leva un pago - distinto- 'que afortunado son por dedicarme ao que me gusta'”.

A precariedade tradúcese en baixo volume de ingresos, na súa intermitencia ou estacionalidade e, tamén, en escasos dereitos laborais, ao operar como autónomos forzosos na maioría dos casos. E a cada crise a situación parece empeorar. Recuperando palabras do economista Pau Rausell, no sector cultural dáse "un paradoxo estrutural difícil de resolver: por unha parte a produción cultural non responde sempre a necesidades de mercado, 
senón á necesidade dos propios artistas de expresarse creativamente; por outra, hai moita xente disposta a facer cultura xa non só sen cobrar, senón incluso poñendo cartos”. E isto só ofrece dúas solucións, segundo o seu punto de vista: "Ou unha regulación moi estrita (de difícil aplicación e que limitaría a innovación) ou que consideremos que o sector artístico merece unha renda simplemente por selo”. Esta idea dunha renda básica, sen perspectiva necesariamente sectorial, é outra proposta ${ }^{36}$ que sobrevoou os debates. Evidentemente, igual que a necesaria posta en marcha do Estatuto do Artista, non entra nas competencias das administracións locais. O que si resulta relevante é non perder de vista esta realidade precaria, especialmente cando se contraten servizos ou se deseñen políticas culturais.

\section{Reflexións "urbano-centristas"para un territorio rural}

Coma en tantos outros ámbitos, a mirada profesional de quen opera no rural galego, especialmente no interior, vese infrarrepresentada en calquera foro de reflexión profesional sobre a xestión cultural. E este documento non é unha excepción, especialmente no referido a identificar estratexias e accións específicas para enfrontar os seus retos.

Parece clara a necesidade dunha maior aposta institucional por impulsar novas análises que permitan superar esta fenda de (re)coñecemento doutras realidades profesionais e amadoras na contorna rural galega. Nesta liña, e contando coa convicción plena do Consello da Cultura Galega verbo desta necesidade, a Comisión técnica de xestión e políticas culturais ten xa en marcha unha liña de traballo centrada especialmente no estudo das prácticas culturais sostibles que están a operar na Galicia rural.

\section{Por que? Para que facemos o que facemos?}

Non é sinxelo pararse a reflexionar cando un ten que desenvolver funcións todoterreo, sen apenas tempo, equipo e recursos. Outras veces o criterio político, non necesariamente cualificado, imponse sobre o profesional, non suficientemente valorado. E, tamén, as inercias acaban marcando moitas liñas de traballo. Todos eles son argumentos recorrentes e comprensibles, cando xorden estas preguntas nos debates profesionais.

Pero tamén hai voces que demandan aproveitar este momento para repensar o sentido e obxectivos do traballo municipal en cultura. Non só en termos de democratización ou democracia cultural, senón tamén poñendo máis en valor o seu propio potencial transformador ${ }^{37}$. E sen ter que estar

\footnotetext{
${ }^{36}$ https://url2.cl/aaY6R

${ }^{37}$ LAGO, S. (coord.) et al. (2013): Pensamentos sobre: que facer coa cultura?, Santiago de Compostela, AGPXC: xestoresculturais.gal/docs/2013_03_05-AGPXC-
} 
xustificándose constantemente en termos estritamente económicos, de emprego ou, incluso, pola súa achega instrumental a outros ámbitos, como o turismo ou a hostalaría.

Desde a principal entidade estatal de investigación en Economía da Cultura e Turismo, Econcult ${ }^{38}$, trasladan constantemente unha idea esencial. Desde a perspectiva económica e con respecto a estes outros sectores (turismo ou hostalaría), a cultura xera máis riqueza por persoa empregada e, polo tanto, é máis relevante en termos de produtividade. Así, parece máis estratéxico que o turismo nos axude a poder producir máis cultura, que non producir cultura para atraer turistas.

Outros datos nesta mesma liña argumental son os que podemos atopar no Informe Anual da Cultura de Santiago de Compostela (2018) ${ }^{39}$, dirixido por Marcos Lorenzo. Resulta significativa a serie histórica, que reproducimos a continuación, sobre a porcentaxe de turistas que visitan centros culturais, asisten a actividades culturais e, especialmente, o feito de que a asistencia a eventos culturais sexa unha motivación moi minoritaria para visitar Compostela.

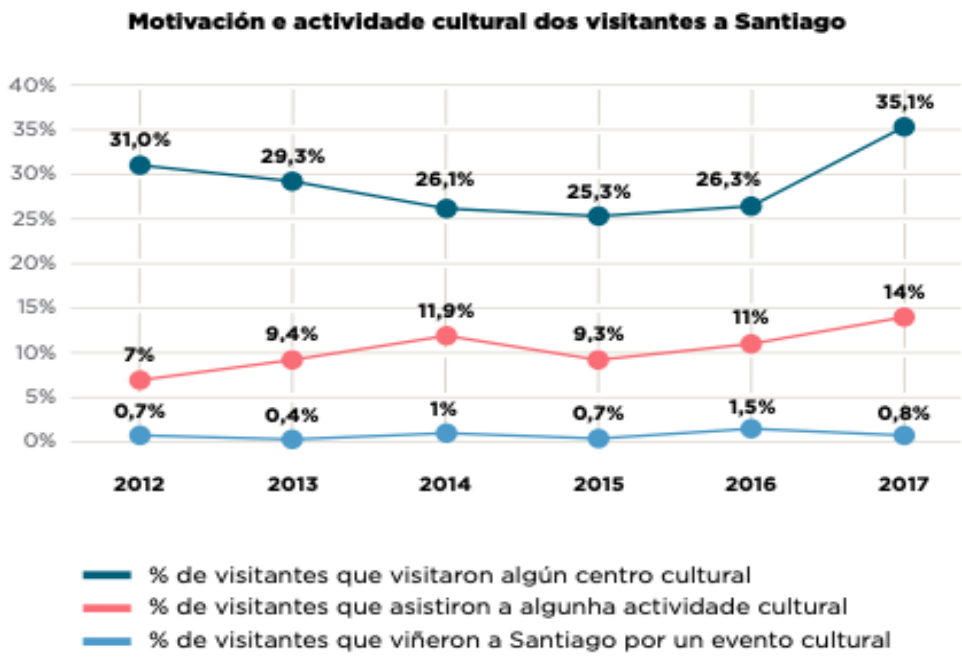

Por finalizar, mencionamos algunhas ideas sobre eses outros modelos que sobrevoaron as reflexións. Principalmente propóñense unhas políticas

que_facer_coa_cultura.pdf

38 Área de Investigación en Economía da Cultura e Turismo da Universitat de València econcult.eu/es/

santiagodecompostela.gal/imxd/noticias/doc/1559718837Informe_Anual_da_Cultura en_Santiago_2018.pdf 
culturais onde teña máis importancia o factor relacional, os dereitos ${ }^{40}$ culturais máis aló do acceso, os coidados entre a veciñanza, o benestar ${ }^{41}$ do conxunto da poboación, a formación dunha sociedade crítica, a participación comunitaria como medidor da saúde cultural do territorio ou a consolidación dun sector privado máis resiliente ante futuras crises.

\section{Como o facemos?}

De como levar a teoría á práctica, habería tantas fórmulas como contextos, pero desde os espazos de reflexión analizados recollemos novos xeitos de facer que poden axudar a marcar as liñas estratexias de cada concello.

Proponse desenvolver políticas de contratación responsable, que inclúan a análise sobre se os prezos por servizos e propostas culturais permiten o traballo nunhas condicións laborais dignas.

Non parece ter sentido, máis aló desta reacción de urxencia inicial, fomentar a longo prazo unha maior produción cultural coa previsible redución de espazos de exhibición ou de vendas, polo agardado impacto da crise económica pos-COVID-19 no consumo e nos orzamentos públicos. A saída desta nova crise non pode ser a través dun modelo sostido por unha maior precarización. Nesta liña apuntan as voces que apostan por un concepto de "ecoloxía ${ }^{42}$ e decrecemento cultural" ou dun enfoque de "artesanía cultural", probablemente unha visión máis realista para o noso sector que a visión imperante de "industria”. En síntese, consiste en apostar por un modelo no que non prime tanto a cantidade de cousas que se programen, senón o impulso de proxectos máis estables e que permitan que os axentes culturais poidan saír de dinámicas de hiperprodución a baixo custo e comecen a traballar en condicións máis estables. Producir menos, pero mellor.

Outro elemento relevante que quedou eclipsado pola COVID-19 é o gran peso que debería ter a sustentabilidade nas políticas culturais do futuro, con

\footnotetext{
${ }^{40}$ Unha referencia inspiradora é a Lei Foral 1/2019, de Dereitos Culturais de Navarra: lexnavarra.navarra.es/detalle.asp? $\mathrm{r}=51081$

${ }^{41}$ SUBIRATS, J. / X. FINA (coords.), N. BARBIERI / A. PARTAL / E. MERINO (2009): El retorn social de les polítiques culturals: de l'impacte social al valor públic, Barcelona, IGOP - UAB. Analiza os vínculos entre cultura, educación, medio natural e saúde: dadesculturals.gencat.cat/web/.content/sscc/gt/arxius_gt/estudi_11_c.pdf. $\mid$ Arts and culture in health and wellbeing and in the criminal justice system. A summary of evidence. Arts Council England (2018): artscouncil.org.uk/publication/arts-and-culture-healthand-wellbeing-and-criminal-justice-system-summary-evidence |Culture, Wellbeing and the Living Standards Framework: A Perspective (2019). Ministry for Culture and Heritage (New Zealand)treasury.govt.nz/system/files/2019-06/dp19-02-culture-wellbeinglsf.pdf

42 bencuriosa.gal/blog/reflexions-sobre-politica-cultural-co-investigador-santiagoeraso-no-ceu-en-xestion-cultural/
} 
outra emerxencia como é a climática, moi presente, pero que tamén abrangue outros retos transversais como a inclusión, a igualdade ou a participación comunitaria, especialmente no espazo público. Unha referencia que seguir é o traballo e a conexión internacional da xerente da Rede Museística Provincial de Lugo, Encarna Lago. Tamén, xa coa participación de Marcos Lorenzo, o traballo da Red Española para el Desarrollo Sostenible (REDS / SDSN-Spain), que acaba de publicar un documento ${ }^{43}$ que analiza as relacións entre a cultura e os 17 obxectivos da Axenda 2030 (ODS) ${ }^{44}$ adoptada pola ONU. Xa no plano privado, podemos destacar os esforzos do Festival Sinsal ${ }^{45}$, que desenvolve unha memoria anual de sustentabilidade coas medidas e resultados acadados.

Unha ameaza anexa á crise da COVID-19, aínda que comprensible a curto prazo, é o aumento do uso de produtos dun só uso e, en xeral, co perigo de abandonar o pouco avanzado en sustentabilidade medioambiental. Ademais da responsabilidade individual, as administracións deberían ser especialmente coidadosas neste sentido. No positivo, a retirada de determinados materiais, como folletos e a busca de alternativas, por exemplo o regreso do uso de códigos QR ou similares, que pode levar a reducir este tipo de materiais funxibles de maneira permanente no futuro.

Outro concepto que xa se avanzou é o de apostar por aumentar a contratación de proximidade, tanto de propostas artísticas como de empresas e servizos auxiliares do noso ecosistema cultural. Esta maior confianza polos provedores de "quilómetro cero" non pode implicar, evidentemente, pechar as portas á diversidade cultural e deixar de buscar a conexión e mestura con propostas artísticas e ideas foráneas.

Seguindo por modelos alternativos á exhibición, que permitan a experimentación, sinálanse os laboratorios de innovación social e cultural, aínda que tamén se pon de manifesto a necesidade de atopar fórmulas e discursos máis accesibles para a poboación xeral. Outra vía son as bolsas e residencias de creación, de especial interese para a xente moza que, a pesar dunha excelente formación, precisa de apoios e confianza para dar os seus primeiros pasos. Só se lles permitimos imaxinar, sen a presión de ter que responder dende o minuto un das súas carreiras a cuestións de mercado e consumo, poderá xurdir unha innovación cultural real. A cal, ademais, beneficiaría ao conxunto do sector público e privado. Como caso de éxito, só hai que botar unha ollada aos resultados das bolsas destinadas á creación

\footnotetext{
${ }^{43}$ MARTINELL (coord.) et al. (2020): Cultura y Desarrollo Sostenible. Aportaciones al debate sobre la dimensión cultural de la Agenda 2030, Madrid, REDS, Madrid. | redssdsn.es/wp-content/uploads/2020/04/REDS_Cultura-y-desarrollo-sostenible2020.pdf

${ }^{44}$ un.org/sustainabledevelopment/es/objetivos-de-desarrollo-sostenible/

45 sinsalaudio.es/festival-sinsal-son-estrella-galicia-memoria-de-sostenibilidad$\underline{\text { social-2019/ }}$
} 
audiovisual, concedidas pola extinta Axencia Audiovisual Galega, dirixida por Manolo González. Un marco de autoprodución e experimentación que lles permitiu aos autores máis relevantes do actual "Novo Cinema Galego" desenvolver os seus primeiros proxectos dende esa mirada singular e persoal.

Sobre como abordar as inercias, sobre todo en modelos con longa traxectoria, un exemplo interesante é o proceso iniciado por Carlos Lorenzo, técnico de Cultura do Concello de Carral. Trátase dunha análise e avaliación do impacto do certame de poesía que levan realizando durante 23 anos. Busca identificar aqueles aspectos que se poderían mellorar no modelo e que probablemente poidan ser extrapolados a moitos outros certames similares.

Finalmente, parece relevante revisar se as convocatorias de axudas en concorrencia responden aos ciclos e lóxicas da cadea de produción cultural que se pretende apoiar. En ocasións, os ciclos orzamentarios administrativos ou a súa convocatoria tardía impiden unha correcta planificación e, o que é peor, xeran dinámicas incluso contrarias ás dos obxectivos buscados, con proxectos feitos ás présas e sen máis finalidade que a xustificación administrativa.

\section{A transformación dixital}

Aínda que este reto estaba xa moi presente, a crise da COVID-19, coa obriga de buscar alternativas virtuais durante o confinamento, mostrou as posibilidades, tamén as fendas, para o labor cultural mediado pola tecnoloxía.

Nun contexto onde o consumo cultural dixital está a concentrarse nunhas poucas redes sociais e plataformas de contidos audiovisuais, preocupa tamén que a visión propia acabe reducida ás valiosas pero testemuñais achegas do sector audiovisual galego entre a inmensidade dos seus catálogos. Así, dentro do enfoque da economía da atención, parece complicado competir polo escaso tempo dos públicos no mesmo campo de xogo destas compañías.

Isto supón un reto especialmente relevante para infraestruturas que garantían tradicionalmente o acceso ao coñecemento e a cultura, como bibliotecas e museos. Agora, que calquera no seu móbil ten acceso a un inmenso volume de contidos culturais, cobra máis sentido que o paradigma da democratización cultural dea paso a modelos onde a estratexia pase pola curadoría e por ofrecer contidos diferentes e próximos. Tamén por incentivar a participación en procesos de creación colectiva nos que as persoas se sintan identificadas como comunidade.

Desde a perspectiva xa repetida de equipos pequenos e profesionais todoterreo, o reto da transformación dixital preséntase como un dos máis complexos, especialmente en termos de reciclaxe profesional. Á espera dunha incorporación de profesionais especializados nas estruturas laborais das 
entidades públicas, parece necesario buscar apoios externos para seleccionar as estratexias e ferramentas máis adecuadas aos obxectivos, contidos e equipos da entidade, priorizando aquelas que despois si se poidan autoxestionar de forma sostible.

A presenza dixital dunha entidade cultural debería superar a simple difusión das súas propias actividades en webs e redes sociais. Un primeiro paso sería actuar de altofalante do que está a suceder no territorio, por exemplo con axendas culturais máis completas e coa visibilización das iniciativas e axentes que operan no concello. E indo un paso máis, a contorna dixital preséntase como un espazo de encontro e participación cultural xa ineludible, onde as veciñas e veciños poden acceder ao coñecemento e ao lecer, pero onde tamén conectan para gozar, aprender, inspirarse, experimentar ou, en definitiva, facer cultura e sociedade en común.

É importante prestar atención aos contidos que de xeito espontáneo ou autoral xa se están a producir na Rede. E tamén abordar un labor de dixitalización, arquivo e posta á disposición do patrimonio material e inmaterial das entidades. Con todo isto poderemos despois xerar narrativas sobre o noso territorio, cun exercicio de curadoría non só en clave de memoria, senón tamén sobre o que está a suceder no momento actual. Aliados relevantes neste sentido deberían ser as novas xeracións de creadores e creadoras, que podemos promover, contratar ou tamén conectar con outro tipo de axentes sociais e veciñais, impulsando propostas de activismo dixital.

Recuperando as experiencias de emisións en liña durante o confinamento, a percepción é que seguirá a explorarse a combinación entre o presencial e o virtual, pola súa capacidade de ampliar públicos. Ao tratarse de programacións financiadas con fondos públicos locais, queda por ver se este modelo de emisión en liña, sexa gratuíto ou non, debería contemplar accións máis aló da promoción de contidos ou artistas do territorio.

A crise da COVID-19 fixo tamén evidentes as diversas fendas dixitais. Máis aló dunha cuestión xeracional, de "persoas maiores que non se saben manexar con ferramentas tecnolóxicas", vimos tamén as dificultades dos supostos "nativos dixitais" ante a contorna educativa virtual. $\mathrm{E}$ a isto debemos sumar as fendas estruturais, de mala conexión, ou as socioeconómicas, con familias que non poden posuír equipos informáticos e pagar unha conexión de calidade. En definitiva, é importante ser conscientes de que hai unha desigualdade no acceso cando traballemos no ámbito dixital e que non se poden desenvolver estratexias en clave exclusivamente xeracional.

En todas estas fendas, o ámbito municipal ten unha función importante para reforzar as competencias dixitais e que a veciñanza no seu conxunto poida desenvolver unha cidadanía dixital plena. Comezando por potenciar os recursos e aulas de alfabetización dixital, pero tamén integrando proxectos desde un 
enfoque máis sociocultural, a través da memoria, o patrimonio inmaterial, fomentando a creatividade..., como o exemplo de Fálame de San Sadurniño ${ }^{46}$.

En conclusión, a estratexia dixital dun concello debe contemplar unha mellor presenza e capacidade de difusión na Rede, pero tamén desenvolver iniciativas que garantan a participación, a inclusión e a existencia dunha visión e un relato propio do seu territorio.

\section{Con que? Con quen?}

Finalizamos con outra clave esencial, que son os recursos humanos, económicos e técnicos que se precisan para unha mellora real da xestión e políticas culturais nos concellos.

No plano do investimento en maiores orzamentos e recursos técnicos, non parece que quede máis camiño que reforzar as entidades de representación colectiva, que permitan unha capacidade de interlocución máis efectiva ante as administracións públicas.

Tamén se reclaman maiores recursos de formación e reciclaxe profesional, con varias iniciativas xa en marcha dende diferentes administracións. Neste ámbito, unha cuestión que se lanza para o debate é se é factible pensar na sustentabilidade dun modelo que recaia sobre todo en perfís todoterreo e cunha media de idade cada vez máis elevada. A necesidade de ampliar equipos e incorporar perfís especializados identifícase como unha demanda xa histórica, tendo en conta o déficit de investimento en equipos humanos das últimas décadas, sobre todo se o comparamos co de infraestruturas, algunhas delas construídas sen proxecto previo nin contidos claros.

Como no ámbito dos recursos estamos ante loitas a medio prazo, unha medida máis inmediata volve ser ollar para o ecosistema máis próximo e apoiarse no sector privado para necesidades especializadas, como a transformación dixital, a creación de medios dixitais, a comunicación, a mediación, a didáctica ou o deseño de proxectos en ámbitos moi específicos.

Outra ferramenta posible para superar as limitacións actuais é promover lóxicas de cooperación. Entre áreas municipais, entre concellos e, xa nun marco case utópico, tendo en conta o punto de partida actual, entre administracións sexan cales sexan as súas cores políticas.

Partindo do máis sinxelo, parece razoable que se unha entidade por si soa non pode soster un servizo ou facer viable un proxecto, seguro que na súa

${ }^{46}$ falamedesansadurnino.org 
contorna existen entidades coa mesma necesidade e problemática. E nestes casos proponse contemplar a opción da contratación coordinada. Hai experiencias recentes que exploraron estas posibilidades no eido da cultura, como o grupo de traballo dentro do Consorcio As Mariñas, unha entidade de carácter supramunicipal integrada actualmente polos concellos de Abegondo, Bergondo, Betanzos, Cambre, Carral, Culleredo, Oleiros e Sada. Tamén o "Quadrilátero Cultural" ${ }^{47}$, promovido polos municipios portugueses de Barcelos, Braga, Famalicão e Guimarães. E, por suposto, as diferentes iniciativas de cooperación dentro do marco de axudas europeas, especialmente de cooperación transfonteiriza entre Galicia e Portugal.

${ }^{47}$ quadrilatero.eu 